\title{
From exploitation to conservation: a historical analysis of zoos and their functions in human societies
}

Marilian Boachá Sampaio ${ }^{1}$, Nicola Schiel ${ }^{1}$, Antonio Souto2,*

\begin{abstract}
Currently there are many interfaces that allow the relationship between humans and animals, including zoos. Throughout history, the change in zoo structure has accompanied the social and cultural changes of human society. Nevertheless, despite the remarkable progress since early zoos were organized, there is still a great need for improvements of zoos around the world. A critical look at the relationship between humans and animals that led to the establishment of zoos was the aim of this study. Zoos currently follow some precepts (entertainment, education, research and conservation), however has not been enough to bind changes in zoos that still lack in accomplishing these pillars. Such lacks create a scenario for discussions between those who believe in the potential of conservation projects developed by zoos and those who find hostile and inadequate to animal life. It can be suggested that the bedrocks were the result of how human beings have perceived animals over time, since perception interferes with the way people deal with what surrounds them. In this way, the merely utilitarian vision of prehistoric times came from the perception that people had about animals at that time. Understanding the evolution of people's perception of animals and how this perception has influenced the configuration of zoos can tell us the directions they can take from now on. We believe that the next step is to turn our attention to the visitors, not only to meet their leisure expectations, but for them to become allies in the fight for biodiversity conservation.
\end{abstract}

Keywords: Zoological Garden; Conservation Centers; Animal Welfare; Zoo Education; Visitor's Perception

\footnotetext{
1 Department of Biology, Federal Rural University of Pernambuco, R. Dom Manuel de Medeiros, s/n, Recife, PE 52171900, Brazil

2 Department of Zoology, Federal University of Pernambuco, Av. Professor Moraes Rego, 1235, Recife, PE 50670901, Brazil

* Corresponding author.. E-mail address: M B S (marilian_boacha@yahoo.com.br), N S (nschiel@yahoo.com), A S (asouto.labet@gmail.com)
}

\section{INTRODUCTION}

Throughout history, the change in zoo structure has accompanied the social and cultural changes of human society (Alves and Lechner, 2018; Dodson and Dong 2016; Famula 2014; Vigne 2011). Initially, animals were farmed in order to (i) complement the diet based on already cultivated plants and (ii) use their physical strength for plowing (ErpHoutep 1986; Famula 2014). With the passing of time, the relationship between humans and animals became more complex, and animals were attributed several others 
cultural values (Alves and Souto, 2015; Gutiérrez-Santillán et al. 2018; ErpHoutep 1986; Vigne 2011). Currently there are many interfaces that allow the relationship between humans and animals, including zoos. These places are found in human societies worldwide and, therefore, have a wide variety of structural and management features [e.g. The Zoological Society of London (2016)].

The first confinements of live wild animals date back to the Paleolithic period, approximately 10,000 BC (Kisling 2001). Several rupestrian paintings depicted the roles of animals in the social life of humans from this prehistorical era (Clark and Piggott 1965). Initially what we now call "animal collections" did not have a specific name. It was only in the XV century that they were called menageries, a name given by the King of France Louis XIV, and from the XIX century onwards, they came to be called "zoological gardens", "zoological parks", or just "zoos", and classified as modern zoos (ErpHoutepen 1986). The structure required for the maintenance of wild animals currently follows some precepts or principles or bedrocks (Fernandez et al. 2009). However, even with the existence of these bedrocks that seek, in a certain way, to homogenize the structural quality of these environments, there are still differences about how captive animals are kept throughout the world.

It can be suggested that these bedrocks were the result of how human beings have perceived animals over time, since perception interferes with the way people deal with what surrounds them [see more in De la Fuente et al. (2017), Hacker and Miller (2016), lannacone and Alvariño (2011), Ogden and Heimlich (2009) and Weiler et al. (2016)]. In this way, the merely utilitarian vision of prehistorical times came from the perception that people had about animals at that time. In this sense, understanding the evolution of people's perception of animals and how this perception has influenced the configuration of zoos can tell us the directions they can take from now on.

It is true that a number of groups, including biologists, environmentalists, members of civil society and government officials have always debated about the relevance of zoos to both visitor and animal life (Bertram 2004; Eaton 1981; Woods 2002). Some believe that zoo structures can be improved by implementing naturalistic enclosures in order to provide both welfare to the animals and a positive perception to the visitors (Cooper 1981); others argue that the simple act of confining animals cannot give them quality of life, because they belong to their natural environment (Jordan and Ormrod 1978), and neither does it enable visitors to create an ideal of nature conservation (Ballantyne and Packer 2016). It is a matter of fact that, given the various contrasting arguments about zoos effectiveness, it is essential to evaluate how the society perception about these environments has changed to the point of the emergence of the four bedrocks of zoos [research, conservation, education, and leisure cited by Fernandez et al. (2009)].

In this sense, this review aims to discuss the history of the relationship between humans and animals in the context of zoological gardens, emphasizing the creation of the zoos bedrocks, under a critical perspective of the most relevant cultural changes of human societies. Throughout this article, it will be possible to understand how people's perceptions and changes in both culture and in the way of thinking have influenced the structural configuration of zoos, animal treatment and the way visitors relate to this environment. Throughout this article, we will discuss the 
basis of the existence of zoos, their purposes, their mistakes and successes, and their importance in light of the environmental changes that are happening worldwide. Finally, we will report the gaps that still need to be filled in order to improve the quality of zoos and the relationship between people and animals.

\section{EVOLUTION OF THE RELATIONSHIP BETWEEN HUMANS AND ANIMALS IN THE CONTEXT OF ZOOS}

According to Loisel (1912), the evolution of zoos is divided into five phases, although we believe that there is also a sixth phase (Figure 1). In the first phase, the confinements did not have a specific name, however, throughout this review, we will refer to them as "animal collections", since this name is used by other authors [e.g. Hancocks (2001), Kisling (2001) and Rees (2011)]. Animal collections arose in the Neolithic period, when humans, who replaced their nomadic behavior with the practice of agriculture, also happened to capture and keep animals to feed themselves and to use their skins to make clothes (Kisling 1998). In the second phase, with the advent of the great civilizations (circa 3,000 BC), the paradeisos (areas delimited by walls under possession of monarchs) were created (Rees 2011). These paradeisos were kept to provide the rich and powerful with leisure activities, such as hunting, as well as gifts among rulers of the great civilizations (for example, the civilizations of Mesopotamia, 3,000 BC, and China, 1,500 BC).

The third phase, was a transitional phase (between $4761453 \mathrm{AD}$ ), in which we believe that animal collections had different characteristics if compared to both the previous (paradeisos) and subsequent periods (menageries), and for which we suggest the denomination of pre menageries. At this time the animal collections already created by ancient

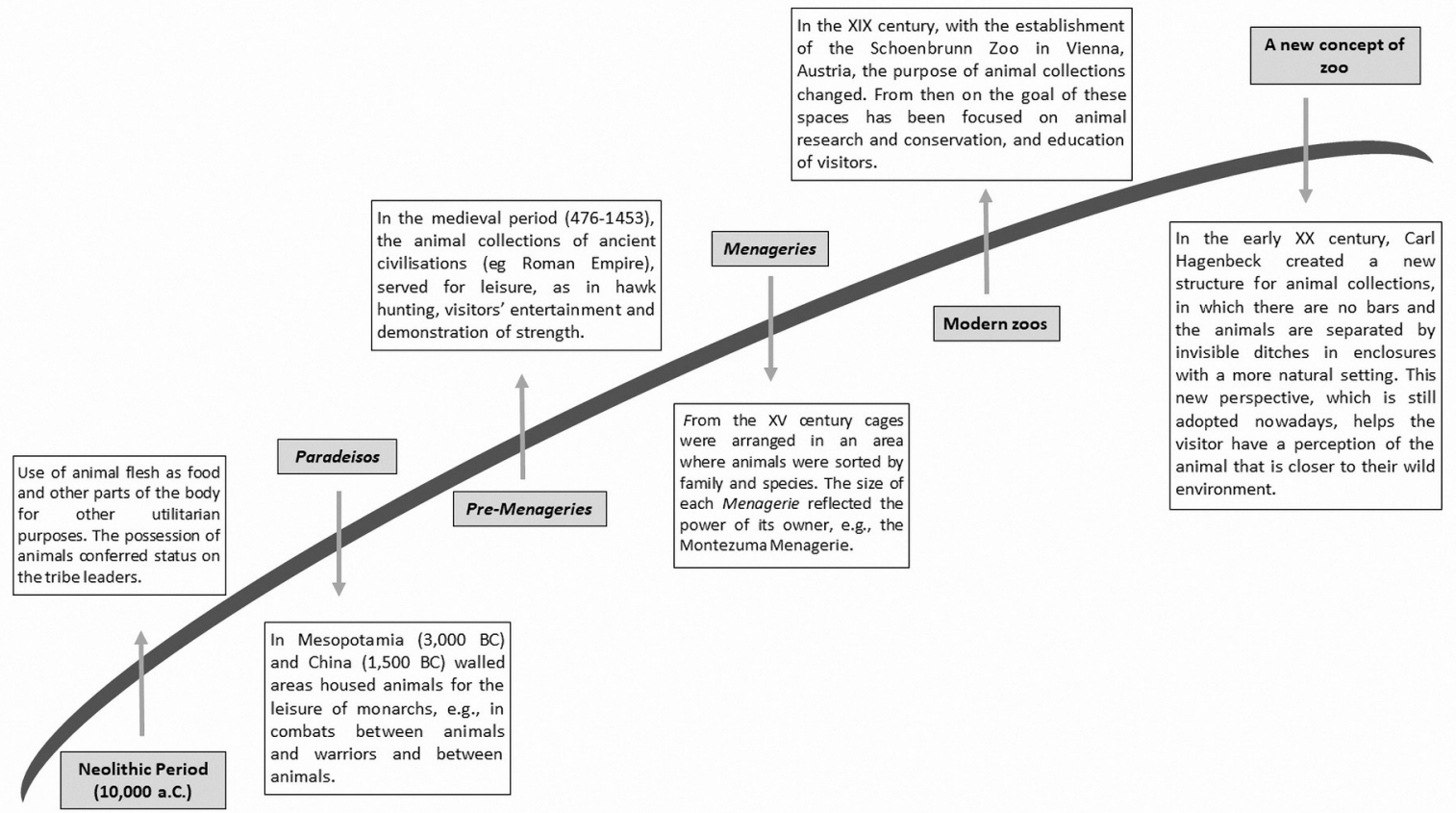

Figure 1. Timeline showing the relationship between humans and animals in the context of the zoo. Information adapted from Loisel (1912). 
civilizations, such as the collections of the Roman Empire, were taken. Many were maintained and served to supply the European collections for monarchs' leisure (in activities such as hunting and falconry) and demonstration of rulers' power (Wood and Fyfe 1943). At that time there was a great expansion of the European culture to Asia, Africa and America, which affected how animals were confined in these exotic lands, making animal collections similar to the European ones. From the mid XV century until the late XVIII century, the fourth phase began, and the premenageries came to be called menageries. This name was first given in France by King Louis XIV when the Versaille menagerie was established and, differently from the collections of the pre menagerie phase, both local and exotic species were placed in cages (enclosures), often separated at the family level, with the purpose of observing the animals and facilitating studies.

In the XIX century the menageries came to be called zoos (which marked the beginning of the fifth and last phase), whose main change was the private and/or public funding, with the expansion of the access to other social classes and the deepening of the research activities on captive animals (Heindl 2015). Created in Germany by Carl Hagenbeck (1844 1913), the new concept of zoo is characterized by a barless structure in which animals are separated from visitors by poorly visible ditches (Hagenbeck 1909). At this time, enclosures started to be shaped to improve animals' quality of life and to provide the visitors with a full immersion into a reality closer to the one found in nature. Concern over the conservation and welfare of animals also gained momentum at this time.

Although in a purely didactic way, the division of zoos history into phases leads us to question which factors directly influenced these changes. This question arises from the need to understand the reasons why there are different types of zoos around the world in terms of quality, whether from the point of view of animals' life or visitors' experience. Since the relationship between people and animals is highly complex, we have to know what are the main ways in which zoos have been carved, which will be explained in details below.

\section{SHAPING THE ZOOS: CULTURE, CREATION OF THE ZOO BEDROCKS AND THE GREAT WORLD WARS}

Observing and knowing animals was the first step that humans took to relate to animals. On average, ancient societies knew and named more than 390 species of animals that they used for alimentary purposes (Berlin 1973). At that time, men lived in a cultural context driven by the constant search for food; hence agricultural crops establishment and handling was a crucial step to reduce the need for locomotion (CluttonBrock 1981). Once agriculture was established, there was a need to keep some animals in the proximity of the crops as a way of reducing hunting efforts. Thus, animals were captured and kept alive in an area for later consumption (Ingold 1994; Louis 1912), and their physical strength was used for farming activities (Famula 2014).

With the emergence of the first civilizations, from $5,000 \mathrm{BC}$, the exploitation process began and humans began to take possession of natural resources, handling and using them according to their needs (Hancocks 1980; Zeuner 1963). By virtue of this, other purposes have been assigned to animals, such as serving as a companions or as symbols of wealth and social status, 
and they were even attributed symbolic values of deities or reincarnations of loved ones (Hancocks 1980; Rees 2011).

The gathering of animals in collections is a more recent phenomenon, which occurred around $3,000 \mathrm{BC}$, with the emergence of the first urban civilizations (Kisling 2001; Schwabe 1994). For example, in the Mesopotamian civilization $(3,000 \quad 2,800$ $\mathrm{BC})$, which is regarded as the first civilization holding captive animals without a strictly nourishing function, taming wild beasts was seen as synonymous with power (Buren 1939; Dalley 1993). In general terms, animal breeding by the Mesopotamian civilization had several faces given that this society had a complex sociocultural structure (Dalley 1993). Some of these animals were treated as luxury items, due to the difficulty involved in their capture and maintenance, and they could only be own by the rich and powerful. In addition, exotic animals that were obtained after a war with other civilizations were kept in areas owned by the rulers as a way of proving their victory. As an example we can mention the animal collector Tiglath Pileser (1,000 BC), who collected several animals from the conquered lands, such as oxen, horses, donkeys, sheep, deer and gazelles and displayed them as trophies (George 1969).

In Mesopotamian civilization, keeping animals in captivity was closely related to economic growth (Bostock 1993; Dalley 1993). Even with the concern for acquiring essential raw materials, business ventures progressed and the rich prospered by increasing the trade in luxury goods (Artursson et al. 2016). Among the traded luxury goods there were several animal species, obtained through confiscation when new lands were conquered or as taxes collected from other peoples. According to Artursson et al. (2016), the exotic animal trade was insignificant at the outset and restricted to a small portion of the wealthier society members. Animal collections were kept in large gardens, in the proximity of areas where several plant species were also cultivated (Finkel 1988). These gardens were reconstructions of whole sophisticated habitats with the capacity to maintain large numbers of animals and plants (Finkel 1988). The gardens built by the Mesopotamians at that time also served to entertain the guests of the royal family.

Animal collections were not exclusive to the Mesopotamian civilization, and in general, the objectives were the same. The Hittites maintained more modest collections than those found in Mesopotamia (Collins 1989). Hunting activities and the magical religious use of animals by this civilization are worth mentioning (Szücs et al. 2012). In ancient Egypt, representations of animals and plants carved on utensils pervaded the Egyptian culture around 3,2002,200 BC. (Erman 1894). Many Egyptian gods were believed to take on animal forms, and other animals were worshiped as gods (Wilkinson 1994). Native and exotic animals and plants were wellknown to the Egyptians, and animal domestication was one of their most important practices (Kisling 2001). However, the territorial extension of the Egyptians was relatively narrow, surrounded by deserts on both sides, crossing the valley of the Nile River, which limited the number of native species (Wilkinson 1994). So, its biodiversity was restricted to a small range of wildlife. This culture was characterized by the maintenance of domesticated animals, such as sheep and pigs, and by the breeding of bees kept in the desert and in private gardens for the extraction of honey (Erman 1894; Kisling 2001; Wilkinson 1994). When the Ptolemaic Greek dynasties (323 
$\mathrm{BCE}$ ) replaced the dynasty of the New Kingdom of Egypt, the city of Alexandria boasted many amenities. Among these, there was the largest collection of animals in the ancient world (Breasted 1906; Dale 2010; Hancocks 2001).

Other important collections of this period were found in Asia, such as in India and China. As in Egypt, the history of China has been marked by alternating periods of unification and fragmentation due to major conflicts, so that in the unification periods animal collections were more stable (Needham 1954). Some Chinese dynasties were known for their animal collections and their gardens, used for the study of nature (Menzies 1994). The founder of the Zhou dynasty, Wen Wang, for example, was the one who built the first known animal reserve (Schafer 1968). This reserve, as well as other royal and baronial parks (parks owned by the wealthy class) similar to those existing in the Zhou period (1,000 $200 \mathrm{BC})$, was large and thus required its own administrators, trustees and veterinarians teams.

In the Christian period (about 2001279 AD), some Chinese emperors (Han, Qin, Tang, and Song) kept several animals in places that resembled menageries for personal use (Needham 1954). Animals, both natives and exotic, were separated by fences (Menzies 1994). Unlike the Mesopotamian and Egyptian collections, which were influenced by other societies, the Chinese collections evolved with little or no external interference (Kisling 2001). This is evident even today. Thus, the way Chinese zoos are structured nowadays can be explained by the way these civilizations related to animals in the past (Bostock 1993). It is worth emphasizing that the relationship of some Asian peoples with animals lacked respect and ethics (Schafer
1968). According to Schafer (1968), wild animals were perceived by some as enemies of the civilization, because they interfered with people's life by raiding crops. In addition, overexploitation, mistreatment and maintenance in inappropriate environments were also part of the routine of these animals.

GrecoRoman societies aimed at achieving an anthropic domination of nature (Lonsdale 1979). The subjugation of natural areas occurred at the climax of Greek civilization (323 BC). Thus, agricultural crops, along with woods, where trees were worshiped as incarnations of the gods, were established in the citystates. The natural areas, as well as their resources, were seen for utilitarian purposes (Lonsdale 1979). The citystates did not possess great riches, which made the establishment of great animal collections difficult. However, Alexander the Great was an exception. In fact, during his kingdom, he kept great collections containing both native and exotic species.

The Roman cultural history shows us that this was a society focused on great land conquests through epic battles (Cornell 2012). The punishment for people who committed crimes was mutilation, crucifixion, hanging and even slavery (Cornell 2012). Similarly, several animals were also tortured for mere entertainment (Jennison 1937; Maehle 1994; Stevens and McAlister 2003). Fights between animals and between humans and animals were an example of this (Jennison 1937; Rees 2011). In contrast with a modern zoo, at that time animal collections were rudimentary places that lacked conditions for animal welfare (Maehle 1994; Scullard 1974).

The Middle Ages (476 1453) were marked by the emergence and consolidation of the great European societies and the 
great navigations. With the end of the Roman Empire, animal collections, when not uncharacterized, were taken over by the European monarchs. Monasteries also hold large estates containing some animal collections (Bostock 1993). The practice of hunting as a sport also gained momentum in this period. Frederick II of Sicily (1195 1250) wrote a manuscript about the art of hunting using falcons, also called the art of falconry (Wood and Fyfe 1943). From his collection located in Palermo, Italy, Frederick II acquired the knowledge about the characteristics and the behaviors of the falcons (Figure 2). This knowledge made him a specialist and an authority in bird biology (Wood and Fyfe 1943).

Land conquests brought animals from different parts of the world to Europe. When Luiz IX of France returned from the Crusade, he brought with him several elephants (Kisling 2001; Osborne 1994). The Vatican collections began to grow with Pope Benedict XII (1285 1342); another religious entity, Pope Leo X (1475 1521), also kept various animals, such as birds, lions and leopards, owned by the church. In England, King John (1199 1216) opened approximately 800 parks, containing various species of plants and animals (Rees 2011).

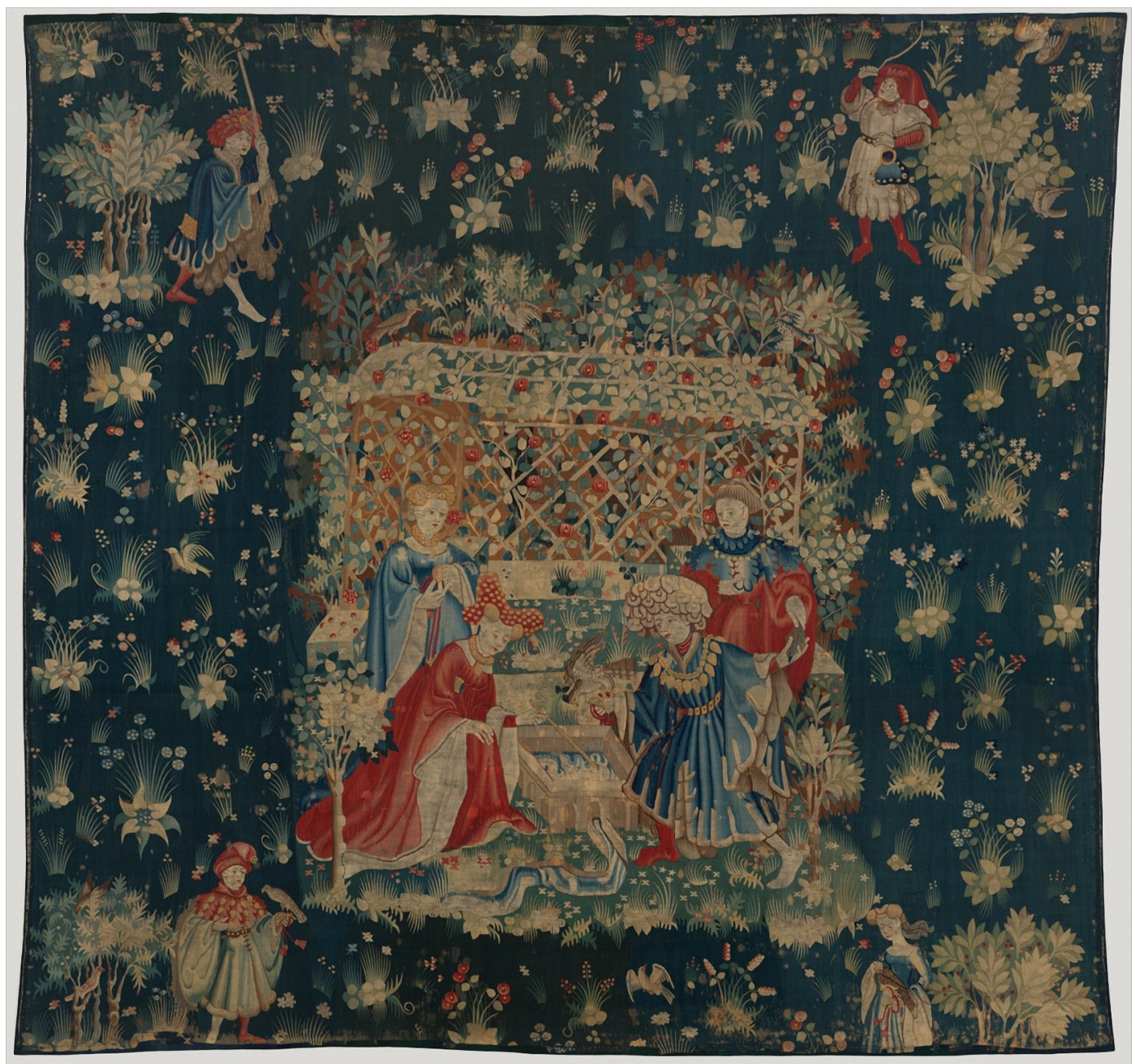

Figure 2. "The bath of the Hawk". Tapestry dated 14001415 showing the preparation of the hawk with a bath in order to make him more docile. These animals were subsequently used for hunting other animals. Public domain image. 
Although animal collections were still a privilege of the more powerful Europeans, the general population could see exotic animals in the medieval fairs (Kisling 2001; Orborne 1994).

Animal collections of important New World civilizations also reached their maximum splendor in the medieval period. Although Aztec's (1325 1521) and Inca's (1440 1533) collections existed long before the arrival of Europeans, they were enriched with exotic species, becoming the largest collections of the New World (Brading 1986; De la Vega and Livermore 1964). The Aztec civilization had a good understanding of the environment, from mineral resources, to plants and animals, which was reflected in the way they used these resources. An example of this was the legendary Montezuma Zoo (Figure 3), a garden covered with a rich vegetation and populated by several animals (Klimczak 2016). According to Klimczak (2016), the Spaniards who discovered the Aztec civilization wrote about the greatness of this zoo, where more than 600 caretakers worked for the maintenance of the animals.

The Inca civilization did not have as deep a knowledge of the animals as the Aztecs, but used various medicinal plants to cure diseases (Kisling 2001). According to Chávez (1980), camelids were the animals most used for various purposes, from feeding and obtaining wool to religious sacrifices. Other animals like dogs were also domesticated by this civilization, while wild animals represented a small percentage of the animals they kept (Bauer 2004).

It was in the Renaissance, when Europe emerged as nationstates and with the increase of power and wealth, that animal collections grew in terms of size and number of species (Grigson 2016; Loisel 1912). Until then there was no specific designation for the confinement of animals. Upon ascending the throne of Versailles in 1661, the absolutist Louis XIV, seeking to expand the gardens of his palace, established the first

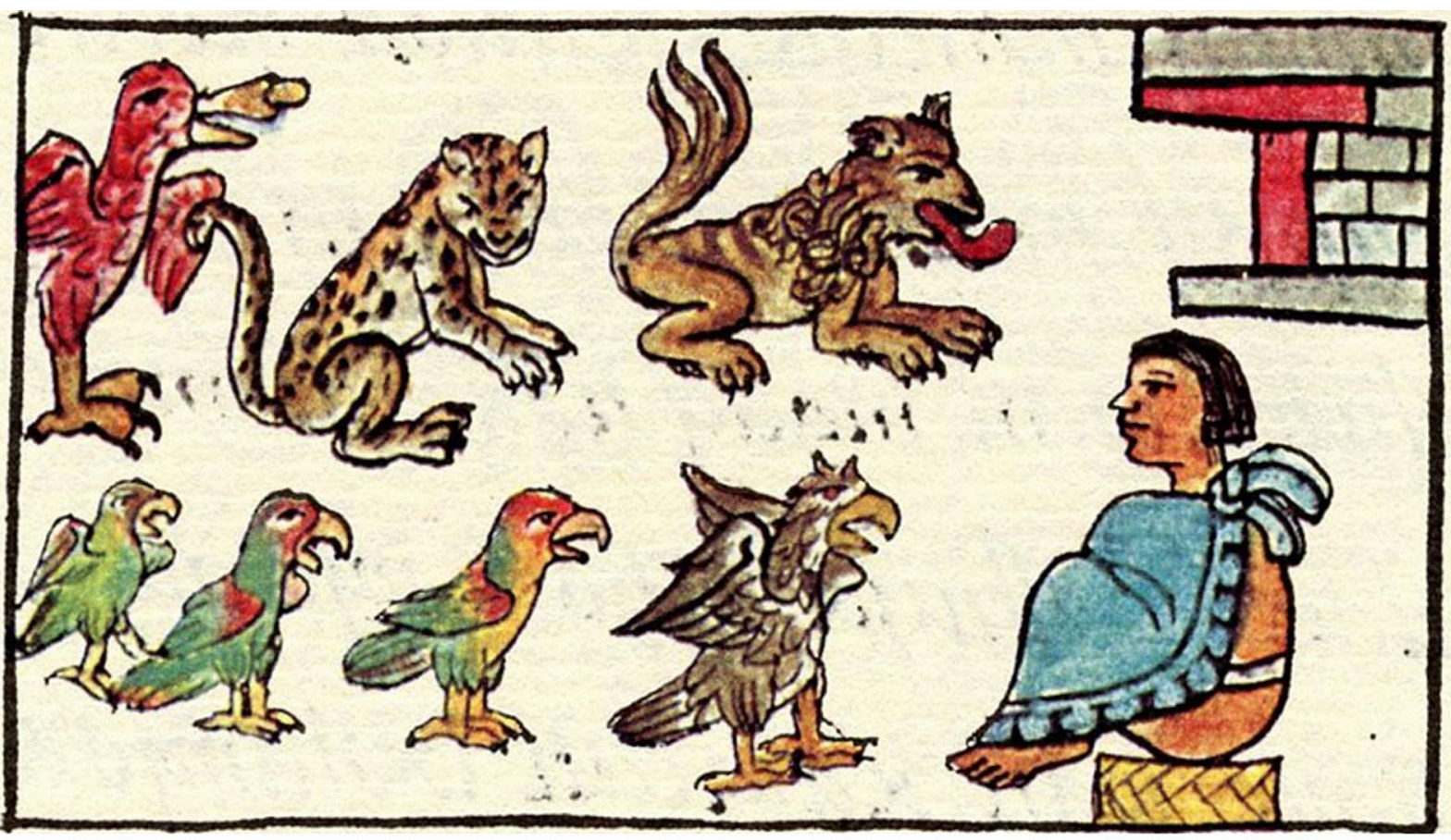

Figure 3. Representation of the legendary Moctezuma Zoo. The image shows the animals of the ruler with one of the 600 animal caretakers. Public domain image. 
menagerie (Sahlins 2012). Like other animal collectors in Europe, Louis XIV attempted to gather the largest number of known species in his menagerie (George 1985). However, just as the representatives of the church, who at that time also confined animals for study purposes, in private animal collections the number of species exceeded the available space, making it difficult to maintain them (George 1985; Kalof 2007).

According to Sahlins (2012), the establishment of this menagerie marked a change not only in the importance given to confined animals, but in the very way of contemplating nature. In general, menageries consisted of delimited spaces (also called enclosures), surrounded by concrete walls and fences, from which the visitor could contemplate the animals (Figure 4) (Grigson 2016). Throughout the XV and $\mathrm{XVI}$ centuries, the growth of the menageries was supported by the extensive overseas exploration. Along with animals native to Europe, many new species were brought from Africa, Asia and the New World (Kalof 2007).

During the colonial period, European countries had quite an influence on other civilizations in Asia, Africa and also the New World. In his report on the colonization of Africa, Crosby (1986) endorsed this statement by reporting that there had been a creation of "New Europes". Preponderantly, European settlers imposed their culture, life habits and even their way of relating to natural resources on the colonized peoples (Osborne 1994; Segawa 1993). Since then, many of these areas have been subject to extensive exploitation of plant and animal resources to meet the needs of the settlers (Crosby 1986). In addition, several animals that were abandoned in the colonies or that

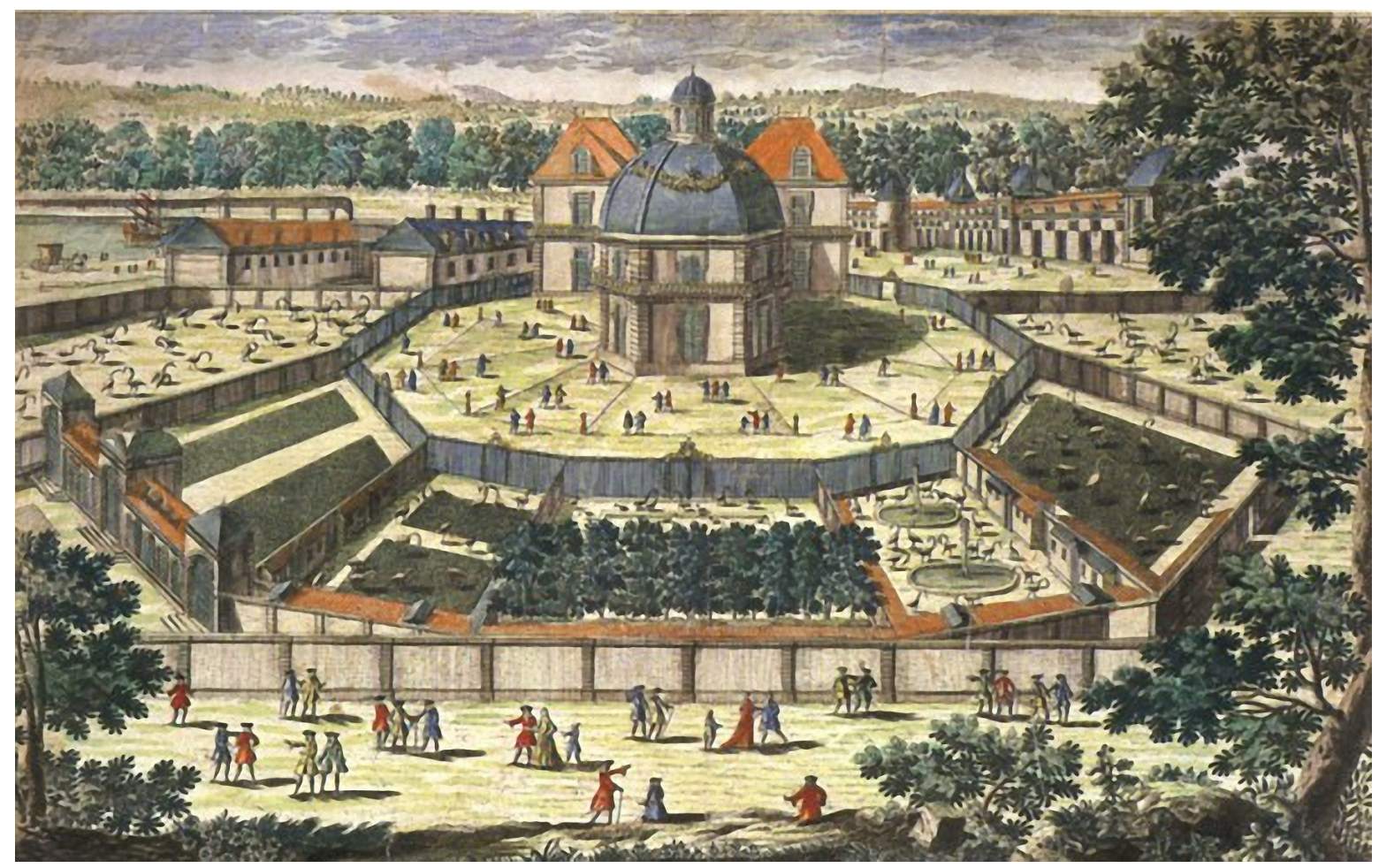

Figure 4. Menagerie built in the Versailles Palace under the kingdom of Luis XIV, 16431715. As we can see, animals were kept in walled enclosures, each of which contained animals belonging to the same species or family, a typical characteristic of the menageries. Public domain image. 
fled ships, spread across these new lands and began competing with local species (Segawa 1993).

During the colonial period, sites of extraction and study of the natural resources existent in the colonies were established (Grove 1995). For example, what is believed to be the first Europeanstyle menagerie of the Americas was built under the Dutch occupation in the Northeast of Brazil (1630 1654) (Almeida et al. 2011). Despite animals were not kept for long in this menagerie (1642 1645), researchers, such as Georg Marcgrave, were given the opportunity to observe and study part of the local flora and fauna. Europeanstyle gardens with medicinal plants built in other countries, such as India, provided a deeper understanding of medicinal plants from the colonies. Many of these plants were sent to Europe for therapeutical purposes (Grove 1995; Kisling 1998). Later, with the decolonization of these countries, some of these gardens could evolve into botanical gardens while animal confinement farms became menageries and then zoos (Kisling 1998).

Just as in Versailles, in Renaissance Italy great importance was attached to the collections of both great rulers and the clergy (Bennett 1829). According to Jacob Burckhardt (1818 1897), the wealth of Italian princes, together with their interest in natural history and the contacts with Arab animals merchants, contributed to the formation of these collections (Burckhardt 1878). Similarly, some information about two $\mathrm{XVII}$ century menageries, found in the Tower of London and in Versailles, report that the collections held a larger number of living specimens than stuffed ones and more native than exotic species (Kisling 2001). George (1980) also documented that the exotic species of greatest interest came from Africa and South America, with very few animals coming from North America.

The values that began to spread from the French revolution (1789) rejected the absolutist ideal of the monarchy, contributing to the endorsement of the ideas proposed by Louis XIV. Between the late XVIII century and the early XIX century, the opening of royal and private menageries to the public paved the way for the creation of modern zoos, triggering further cultural change (Brown 2014; Knowles 2003). From this event, these structures underwent several changes so that they could meet the needs and curiosities of all visitors. Thus, from the XVIII century, a philosophical and scientific change was perceived in the way the animals were kept in the menageries, converting them into zoological gardens (Knowles 2003). Generally speaking, these changes of conceptions provided an improvements in the relationship between visitors and animals in four ways: (i) attempting to make the enclosures more similar to the natural environment; (ii) contributing to the management of natural biological resources; (iii) educating people to adopt more sustainable lifestyles, and (iv) improving knowledge of animals through scientific studies. However, these changes have taken a long time and are still occurring, since the way that people perceive animals does not change easily (Knowles 2003).

In 1752, the doors of the Schönbrunn Zoo (or Tiergarten Schönbrunn), which is considered the first modern zoo, were opened in Vienna (Figure 5). Consisting of 12 cages of the same size, such as the Versailles menagerie, from which it was inspired, the Vienna zoo opened its doors to the general public as long as decently dressed in 1778, on Sundays only. Other zoos also began to open their doors to the public: the Madrid Zoo (1772), the Paris Zoo 
(1793) and the London Zoo (1828) (Brown 2014; IUDZG/CBSG 1993). It is worth mentioning the importance of the Paris Zoo, known as Jardin des Plantes [the Plants Garden] and considered to be the first research center introduced in a modern zoo.

During the tour, the visitor had the possibility to know more about the animals in the zoo through short lessons that were given along the route. However, due to the curiosity of its visitors, the purpose of modern zoos at the beginning was primarily entertainment, as in previous stages, with little focus on increasing visitors' knowledge and on animal welfare (Woodland Park Zoo 2015).

As a result of the growth of the number of animals in zoos during the 1800s, zoos began seeking financial support by imposing fees on visitors or by government incentives such as tax abatement (Hoage and Deiss 1996; Rothfels 2002). The payment of these fees made the visitors' expectations higher, increasing the zoo managers' concern with zoo keeping (Hoage and Deiss 1996). Furthermore, the creation of animal protection laws supported by the government has triggered the introduction of an ethical concept in the possession and maintenance of animals (Cooper 2003; Stevens and McAlister 2003).

Worldwide biodiversity mass extinction brought with it the need to use the zoo as a place to learn about animals which, in turn, would contribute to their conservation (Knowles 2003). As a consequence, in the late XIX and early XX centuries, some zoos evolved into bioparks or conservation parks (Conway 1995; Robinson 1987). The natural and ecological history of the species kept in the zoo came to be increasingly valued by scientists and visitors (Stevens and McAlister 2003). Thus, gaining a more in depth knowledge about animals required a closer look at their welfare, so that they could develop their behaviors as they do in

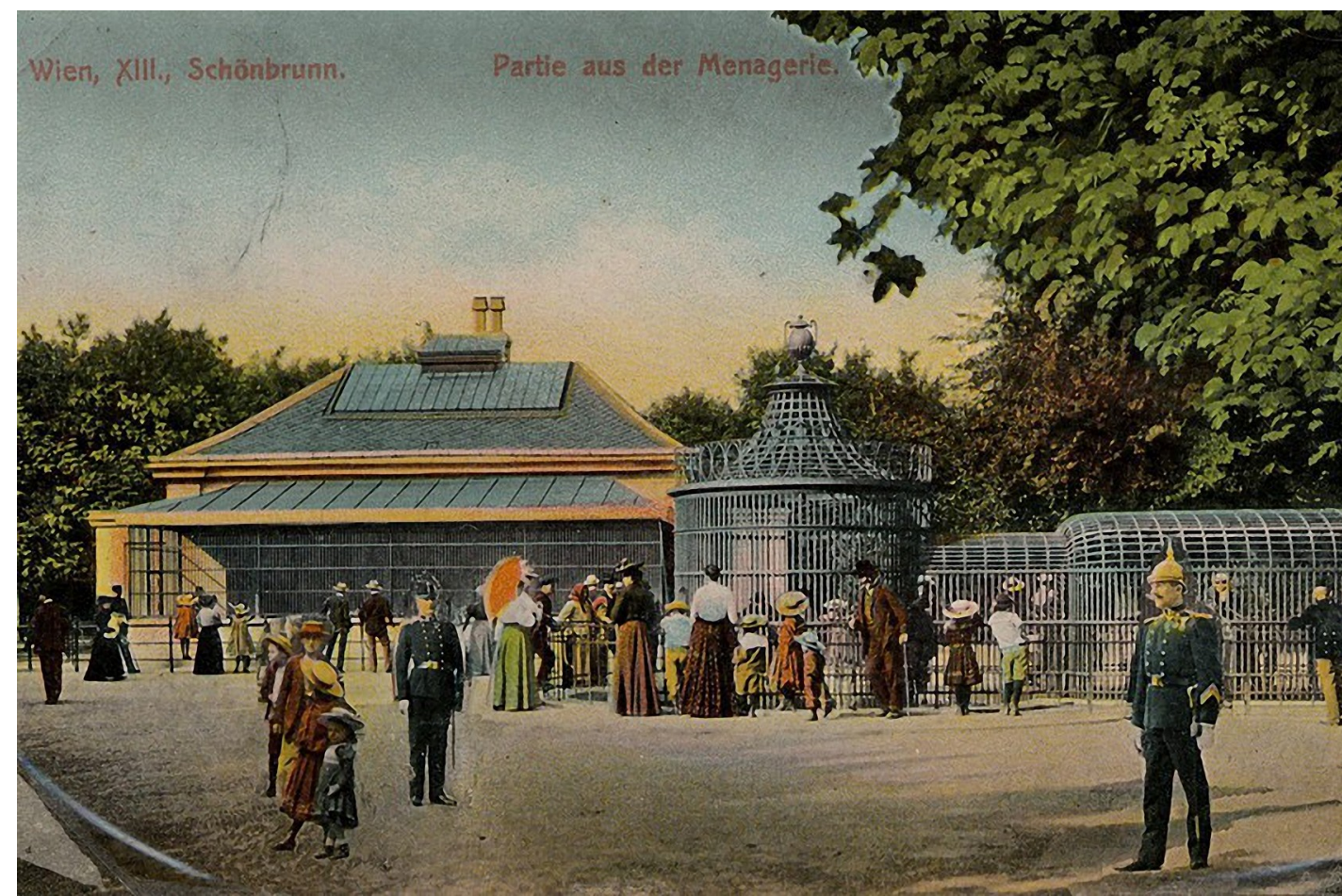

Figure 5. Tiergarten Schönbrunn, Vienna in 1752. Printed with permission. (๖) Archive Zoo Schoenbrunn/Vienna. 
their natural habitat (Rothfels 2002; Stevens and McAlister 2003).

From the XIX century, zoos were also influenced directly by the bourgeoisie and socioeconomic changes. The new and frenetic social configuration stemmed from the industrialization and urban expansion influenced the aesthetic configuration of these environments, since fragments of nature were immersed in the middle of concrete jungles (Wirtz 1997). According to Wirtz (1997), the hierarchical disposition of the animals in the zoo reflect the perspective of domination and subordination between classes found in bourgeois society. In London, for example, where the industrial revolution had its cradle, the zoo came to be articulated as a new project of urban and social development of the city.

The possibility of access by the general public to animal collections brought the idea of wildlife capitalization. Several animals from various parts of the world were already displayed for the financial advantages they brought. By virtue of this, in capitalist societies, zoos have come to be seen as a business, having to meet the visitorpayer expectations and bring financial return (Kellert 1993; Wirtz 1997). As a result, Mohnhaupt (2016) points out that the goals have changed and the way that zoos started to relate to each other was often based on the competition to raise more money.

In addition to socioeconomic aspects, other events have influenced the structure and treatment of animals in zoos, such as the great world wars. Entertainment, education and scientific work developed by zoos began to lose importance during the war (Howell and Neal 2012). Robeyns (2012) documented, in its study on the Antwerp Zoo, that World Wars I and II compromised much of the structure and funds for this institution. In this sense, the author states that the wars were a great impediment to the continuity of zoo evolution, mainly regarding their improvements on animal treatment and visitors' receptiveness.

Another example of the impact of the great wars can be seen in the first modern zoo, the Schönbrunn Zoo in Vienna. Despite the attempts to keep it running smoothly, the Schönbrunn Zoo was gravely affected by the recruitment of its staff to serve in World War I. In addition, in 1921 the number of dead animals reached dramatic levels, dropping from 3500 to about 400, and part of the zoo structure was bombed (Heindl 2015). What could become the best zoo in the world at the time [according to Loisel (1912)], almost closed down. Many other European zoos have suffered from the World Wars, such as the Munich, Frankfurt and Berlin Zoos (Figure 6). Due to bombing, several animals were killed either by the bombs or, when they fled, because they were shot down for security reasons, or they were plundered from the zoos to serve as food for the refugees. Some surviving animals were used as labor force during this period, others starved to death due to lack of resources (Heindl 2015).

Zoos began to receive a lot of pressure from people who questioned why animals received large amounts of meat while they had no food (Heindl 2015). According to Howell and Neal (2012), zoos can show much more about people and their "humanity" than about animals, given the form of governance and how we deal with governance in the midst of major conflicts. Historical records point out how animal care lost relevance in that period.

After the end of World War II, rebuilding bombed zoos was a way to bring back the joy and dignity of the people of the affected European countries (Robinson 1992). The 


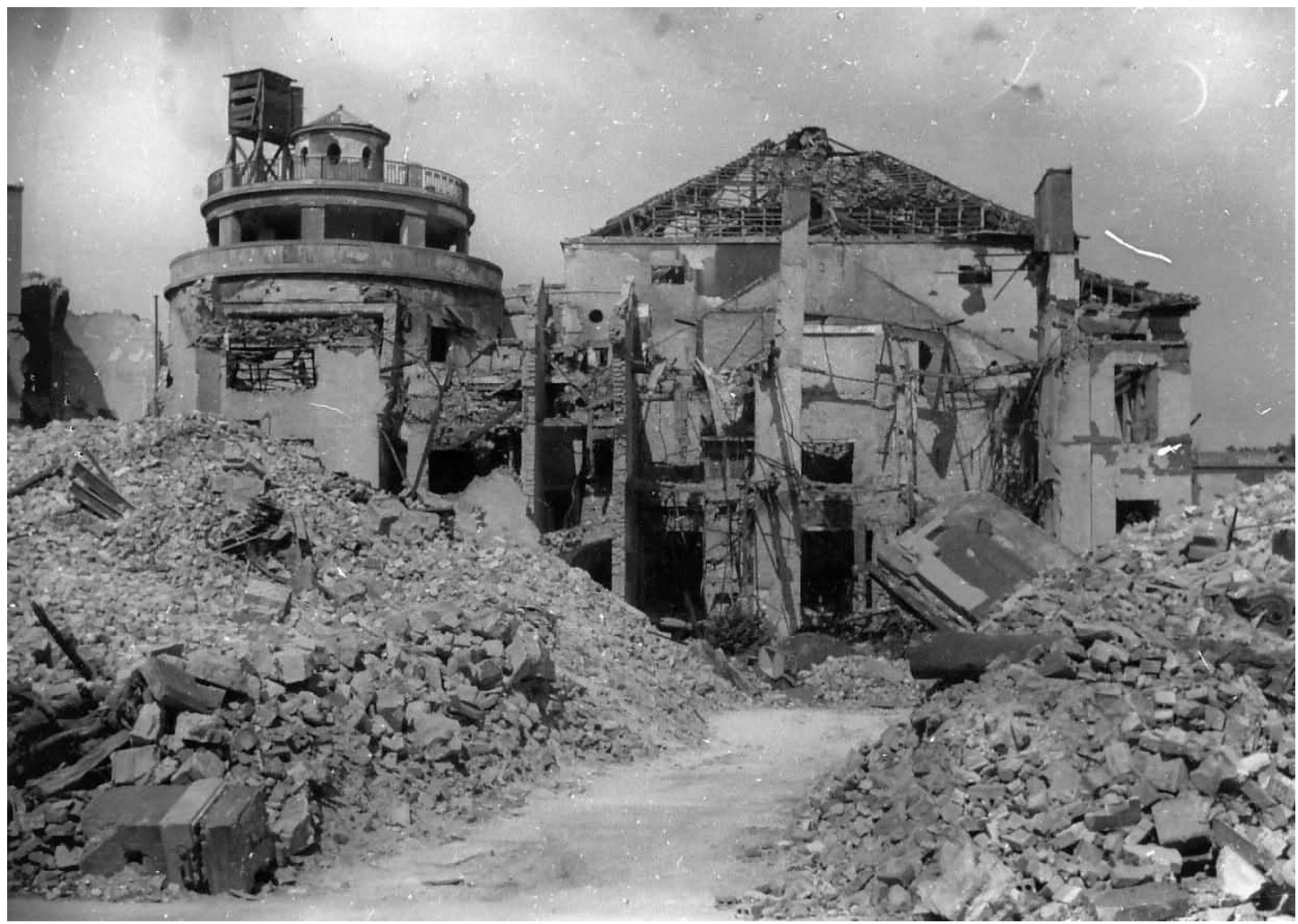

Figure 6. Ruins probably from Berlin Zoo Aquarium after bombing during World War II. Public domain image.

postwar period was marked by efforts for economic development, but investing in the reconstruction of zoos also contributed to the perception that countries were growing (Robinson 1992). The reestablishment of alliances between the nations was necessary for this economic reconstruction. The practice of giving animals as diplomatic gifts can also be observed in the postwar period. According to Lawrence (2012), some animals, such as platypus, served as diplomatic gifts for the reestablishment of dialogue between Great Britain and Australia.

What we can conclude is that not only during the two great World Wars, but also in other wars and other type of conflict, animal care has been compromised (Bagarinao 1998). Hence, it can be said that zoos have to cope with the socioeconomic situation and with the country's conflicts to be able to thrive.

\section{EFFECT OF THE ZOO BEDROCKS ON ANIMAL TREATMENT}

As seen, zoos were strongly shaped according to the cultural basis of societies. The four bedrocks or principles at the base current zoos entertainment, research, education and conservation emerged during social changes (Fernandez et al. 2009). Although these precepts are considered together in current practices developed in zoos, we address and evaluate them separately in this article for educational purposes only.

The use of animals as a form of entertainment was the first bedrock to be developed in zoos (Kisling 2001; $\quad$ Rothfels 2002). However, currently there is a general idea that wild animals should not be confined 
solely to this end. According to some authors, zoos bring benefits to society [e.g. Birney (1997) and Coe (1986)], while others say that these places should be closed down [see Acampora (1998) and Jamieson (1985)]. Of course, for people in an urban context, encounters with wild animals are likely to be relatively uncommon, limited to small birds and mammals that have adapted to these sites, or even casual encounters in areas close to forest remnants (Beardsworth and Bryman 2001). That said, people who believe in the importance of environments such as zoos anchor their ideas in the perspective that the visitor can learn about animals and, in turn, learn to have a better attitudes towards the environment also outside of the zoo (Miller et al. 2004; Patrick et al. 2007). On the other hand, people who criticize zoos base their opinion on the poor conditions of these places, assuming that they would not provide a pleasant environment for the animals which, therefore, would have a bad quality of life (Acampora 1998; Eaton 1981). The two statements may be true. In fact, some zoos have really countless issues and we cannot ignore them. However, the benefits that good zoos can bring to society, contributing to people's education and providing moments of contact with nature, are undeniable.

Despite these debates about the existence of zoos, the fascination with captive wildlife attracts more than 700 million people every year to such places (Gusset and Dick 2011). According to Eaton (1981), the term recreation can be considered as "recreation", insofar as the individual acquires new insights from new experiences through an activity. However, today's recreation in zoos alone does not meet the expectations of most visitors (Woods 2002), suggesting that it should be associated with other zoos bedrocks such as education and conservation.

In fact, zoos are traditionally recreational environments, along with parks or picnic facilities, as these come from the menageries, which had this purpose (Kisling 2001). In this regard, we must remember that this experience in itself is dignified and should be valued, since it reconnects people with nature and arises feelings that can influence the attitudes towards animals (Miller et al. 2004; Sampaio et al. 2018). Ultimately, most visitors to a zoo find, in addition to recreational pleasure, comfort, shelter and aesthetic appreciation, nurturing their biophilic potential (Wilson 1984). Thus, the entertainment precept can act as a gateway to the changes that may occur in the relationship between people and animals when they also access educational programs developed in zoos (Carr and Cohen 2011).

One should not leave aside the thought that the better a zoo is for its animals, the more attractive it becomes for visitors (Tomas et al. 2002). On the contrary, an environment that is unpleasant for animals cannot bring good impressions on animal life (De la Fuente et al. 2017; Rothfels 2002). It was from this perspective that the animal trader Carl Hagenbeck (18441913) proposed changes unimaginable at the time at his zoo, Tierpark Hagenbeck, at the end of the XIX century. From his experience in animal trade in circuses and shows, Hagenbeck had the chance to understand animal needs and also that when they looked good and healthy the spectators had a better experience (Rothfels 2002).

In the 1890s, Hagenbeck developed a new panorama in the setting of zoos, inserting animals of different species in the same enclosure, decorated with plants, earth and artificial rocks. This new perspective, developed by him in 1896, gave the visitor 
the idea that the animals were in their natural habitat, leaving them in awe (Rothfels 2002). With the help of the artist Urs Eggenschwyler, he created Carl Hagenbeck's Tierpark, founded in 1907 in the town of Stellingen, near Hamburg, Germany (Rothfels 2002).

Changes to meet public needs have helped strengthen the other bedrocks, since visitors have become more critical and eager for environments closer to nature. An animal collection should be a system having a recreational purpose, but also providing animal welfare, education to visitors, research and help in the conservation of nature (Fernandez et al. 2009).

With increasing environmental degradation and the extinction of countless species, zoos became the only places where most people could observe wild animals and thus learn more about them (Rees 2011). Woollard (1998) argues that education has always existed in zoos, as Chinese and Egyptian collections in ancient times have served to see and learn about the various forms of life. Nowadays education can be considered the key to all the other bedrocks of zoos (Woollard 1998). In this sense, Andersen (2003) believes that zoos can contribute to a deeper learning about animals, influencing people's perception of about nature and, in turn, their actions.

Educational practices in zoos became more frequently observed in the pre menageries period (Woollard 1998). Visits of school groups were introduced in the XIX century in order to boost students' curricula and the concept of ecological immersion was introduced in the XX century (Ress 2011). In the first decade of the XXI century, as a result of the implemented educational practices, zoos began to seek a more ethical approach to the maintenance of their animals (Ogden and Heimlich 2009).
It seems that even today the great challenge of zoos is to turn a moment of leisure into an educational moment as visitors seek these places for fun and not necessarily education. In this way, zoos must engage visitors in educational activities that attract and inspire them to adopt an environmentallyresponsible behavior (Ogden and Heimlich 2009). However, according to Heneson (1981), the type of education provided by zoos should be reevaluated, as it is based on the exploitation of the animals on display. The author questions whether the educational aspects addressed in zoos are sufficient to silence the ethical issues behind the confinement of wild animals.

The Zoological Society of London, founded in 1826, sought to demonstrate that zoos played a key role in spreading useful knowledge and promoting rational amusement and thus in showing the importance of species conservation (Woollard 1998). According to Ress (2011), by replacing popular animals with rare species of greater ecological concern, zoos can apply ethical considerations to their collection plans and reinforce their importance in the conservation field.

The development of educational and conservational activities can set goals for the acquisition of knowledge and, subsequently, the change of attitude and behavior by the visitor (Seidensticker and Doherty 1996). Patrick et al. (2007) believes that it is possible to change people's consciousness, attitudes and behaviors in relation to natural resources. To this end, it is necessary that zoo managers formally establish the role of the institution by investing in professionals who effectively contribute to visitors' education (IZE 2016).

To assist the zoos in this mission, the International Association of Zoological 
Educators (IZE) was established in 1972 with the mission of promoting education as the most useful aspect of zoos (IZE 2016). In 1978, through the Tbilisi Declaration, UNESCO proposed the establishment of new parameters regarding the behavior of people, social groups and society in relation to nature (Ogden and Heimlich 2009). Already in the 1980s, some zoos created a department specifically engaged in education, primarily to meet school demands and provide a better experience for visitors (Woollard 1998).

From the early 1990s, zoos began to address a wider range of topics providing as well information about species natural history, diversity, animal welfare and responsibility of human beings in conservation (Figure 7) (Woollard 1998). With actions beyond the boundaries of zoos, educators continued to seek more effective means to teach to their visitors (Woollard 1998). However, it is still necessary to advance in studies that assess the effectiveness of educational programs implemented in zoological institutions (Moss and Esson 2013).

From the XIX century, several scientific societies have begun to invest in wildlife studies, creating and transforming zoos into research centers (Hochadel 2005). In fact, science in zoos has begun at the end of the XVIII century with the opening of the Jardin des Plantes in Paris. According to Hoage and Deiss (1996), the creation of the Jardin des Plantes, together with the Foundation of the London Zoo (1828) and the publication of the book "The Origin of Species" by Charles Darwin (1859) reflected the interest in investigating and better understanding the animal world.

The French Revolution, already mentioned in this review, was the milestone for the society transformations that culminated in changes in the bedrocks of zoos. For what concerns the bedrock of research, the opening of the Jardin des Plantes was a symbol of freedom for the nation, in light of the end of the feudal society, and the valorization of natural sciences (Strehlow 2001). Consequently, the research in zoos propagated substantial changes in terms of the enclosures and the quality of animal life, from then on, craving to obtain a greater knowledge of their biological, physiological and behavioral aspects (Hochadel 2005).

Hoage and Deiss (1996) listed 33 zoological gardens opened in the XIX century, including the abovementioned Jardin des Plantes, opened in the late XVIII century, in most of which the objective of

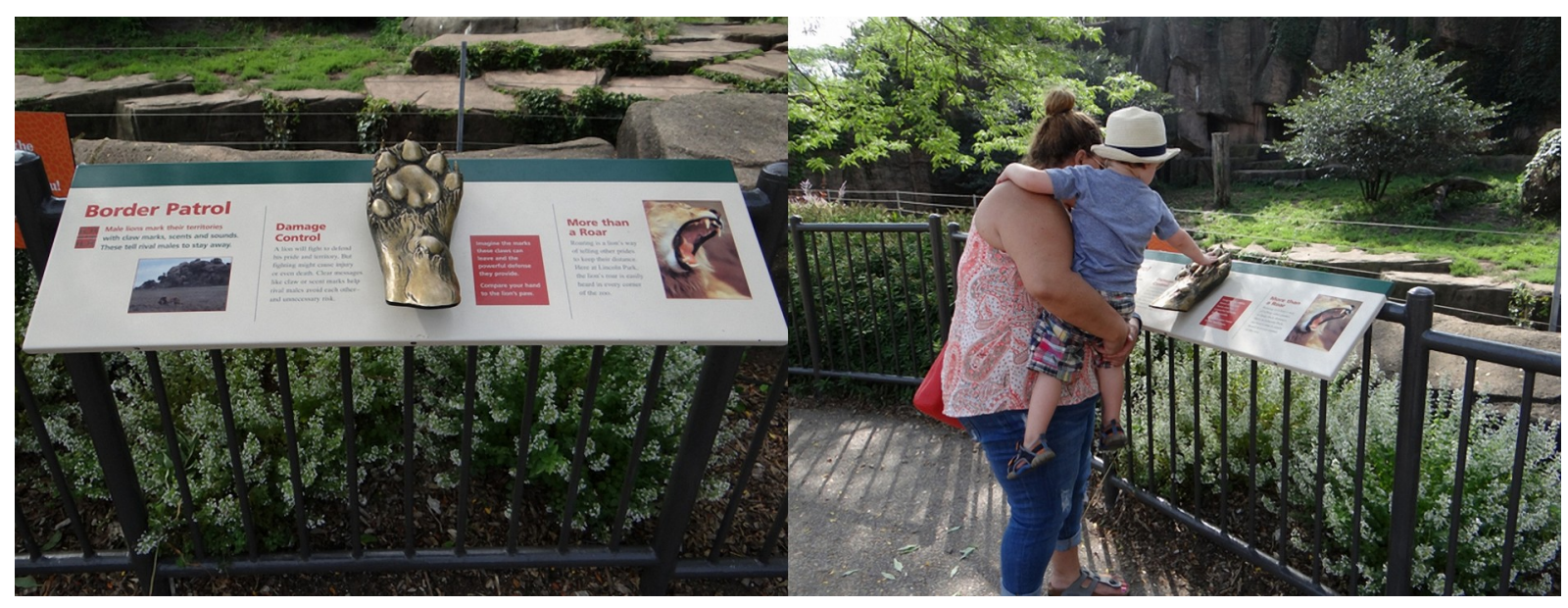

Figure 7. Interaction of visitors in the educational structure installed in the Lincoln Park Zoo (Chicago, USA). Printed with permission. Images kindly provided by Abreu F. and De la Fuente MF. 
scientific studies prevails. The search for knowledge in these institutions became common, because the potential contribution to the knowledge of the various forms of life in the world was latent (Hochadel 2005). Zoology, for example, came to be considered an applied science that involved the acclimatization of several species to other environments.

The Imperial Zoological Society of Acclimatization was founded in 1854, and the Zoological Society of Acclimatization was founded in Great Britain in 1860, with the purpose of habituating the animals to climates different from those found in their original habitat, seeking the biological, physiological and behavioral adaptation to the zoo of destination (Strehlow 2001). Acclimation played an important role in the transfer of several species in the colonial period, in particular animals from Africa, Asia and Australia that were taken to European zoos, emphasizing that the goal of colonialism was purely a utilitarian one (Kisling 2001; Osborne 2000).

Many animals could not resist the long journeys, the weather conditions or simply could not adapt to the captive environment. Scientific studies paved the ways for the globalization of zoos, turning them into references for the knowledge of animal life worldwide (Kleiman 1992). The knowledge gained by scientific studies carried out in zoos with the acclimatization centers at this time was immense. As an example, Frédéric Cuvier (17731838), associated with the Jardin des Plantes, developed several studies with laboratory samples which could not be collected from wild animals, being important for the development of the modern natural sciences (Coleman 1964; Strehlow 2001). Richard Owen studied kangaroos in Regents Park Zoo in 1832 and documented the development outside the womb and the use of milk as energy supply in these marsupials. Kleiman (1992) states that behavioral studies in zoos were important for management practices which would be adopted later, as well as a basis for the whole science of animal behavior. It is worth noting, however, that there was a high loss of species (D'Elia 2010; Osborne 2000; Strehlow 2001). In addition, bringing exotic animals from the colonies to Europe also had a negative impact also on the health of the European population, due to the spreading of diseases, and on the environment, due to the spreading of invasive species and the rampant use of animal species to feed both the zoological collections and the Museum of Natural History (D'elia 2010).

Despite the problems in moving exotic species to European zoos, they have been able to provide a solid ground for high quality basic and applied science (Eaton, 1981). Thus, thanks to these institutions, it was possible to shed a light on various puzzles about the new species, including systematic analyses (Mayr 1942). Richard Owen (1804 1892), a British biologist, comparative anatomist and palaeontologist, for example, had the opportunity to dissect various primates, among them an orangutan (1830), a chimpanzee (1835) and a gibbon (1839) (Rupke 1994). From these kind of studies, the zoos had started to the stage for diverse debates concerning the origin of the species. The great naturalist Charles Darwin used the London Zoo to study the reproductive habits and the hybridization in birds, paving the way for its model on the emergence of new species (Darwin 1868; D'Elia 2010; Stauffer 1975). After the evolution theory was proposed by Darwin [in 1859], visitors came to the zoo with the desire to draw their own conclusions about the theory of sharing a common ancestor with other primates 
(Hochadel 2005).

Research in zoos was consolidated during the XIX century, and in the XX century it became the basis for the improvement of all the zoo services, as a crucial reference for the management of several aspects of the zoo. Animal display, the influence on visitors' interpretation about what they saw, animal behavioral requirements and the success in conservation programs depended directly on scientific studies (Eaton 1981). It is possible that in situ conservation programs, specifically, would not have had the same success if ex situ studies on wild animals had not been carried out, in particular with regard to the development of techniques for studying wild animal populations (Eaton 1981).

According to Ryder and Feistner (1995), captive studies were necessary to foster field study. This flow of information from the zoos to field scientists help provide new insights into the species biology (Feistner and Sterling 1994). On the other hand, data collected in the field have helped intensify efforts for captive breeding. In this sense, Kleiman et al. (1986) documented that the detailed knowledge of the natural behavior of golden lion tamarins was fundamental to facilitate the reproduction of captivebred individuals and their subsequent release, by helping populations that were approaching extinction to grow.

There were three phases in zoos that preceded animal conservation practices and served as a base for the formation of this bedrock (Rabb and Saunders 2005). During the first phase, in the XIX century, taxonomic and systematic studies were encouraged, by verifying the adaptation of the animals to different environments through acclimatization (Gippoliti 2005; Mayr 1942). In the second phase, throughout the XX century, the animal ecological aspects and behavioral biology were studied, evaluating the habitats of the animals (Kleiman 1983; Kleiman et al. 1986); moreover, the enclosures came to include concrete structures that looked like sculptures or human habitations. As institutions, zoos sought the development of their professionals and cooperation with other zoos to manage species. Finally, since the last decade of the XX century and to this day, besides the deepening of biological studies, the genetic mapping of the species has become a focus of attention (George et al. 1993; Harley and O'Ryan 1993; Ryder and Chemnick 1993). Thus, the bedrock of conservation emerged because of a broader perspective, that is, the stimuli for the care of captive animals intended to extrapolate their spaces, also contributing to in situ conservation. For this, visitors are invited to immerse themselves in displays whose objective is to represent a natural ecosystem environment, taking into account the importance of species for the balance of nature. Cooperations between institutions are consolidated in organizational networks for wildlife conservation (Kelly 1997).

The growing threats to biodiversity at the global level (Green et al. 2005; Meffe and Carroll 1997; Primack 2002; Soulé and Noss 1998) have highlighted not only the need for conservation measures but also the need for a change in the mentality adopted since the first industrial revolution of 1760 , which is essentially based on the consumption of resources (Goudie 2013). Until the end of the XIX century, menageries and zoos needed the capture of wild animals because they could not stimulate reproduction in captivity (D'Elia 2010; Frankham et al. 2002). In this sense, D'Elia (2010) points out that the race to feed rare species collections in museums and zoos had unwanted 
consequences, leading to the extinction of several species such as Pinguinus impennis. In 1854, after being declared extinct, $P$. impennis was once again seen in Iceland, attracting the Englishmen Alfred Newton and John Wolley who, upon sighting the specimens, were only concerned with collecting and acclimating them to the Museum of Natural History, causing their extinction at once (Fuller 1987; Gaskell 2000). The Convention on International Trade in Endangered Species of Wild Fauna and Flora (CITES) regulated legal trade and the fight against illegal wildlife trade only in 1975 , restricting the capture and transport of endangered specimens worldwide.

The extinction of several other species of birds due to human activities, which had been already observed by ornithologists at the end of the XIX century (Coues 1876; Meyer 1889), has led, in the two subsequent centuries, to research aimed at reducing these losses (Goudie 2013). The research and education of visitors in the zoo began to envisage the consolidation of sustainable practices in society, in an attempt to minimize impacts to biodiversity. The $X X$ century was the stage for many debates about nature conservation, such as the United Nations Conference on the Environment (Stockholm in 1972, Rio de Janeiro in 1992, Johannesburg in 2002 and Rio de Janeiro in 2012), which has led modern zoos to become much more strict in following the conservation principle in all their operations. According to Hutchins (2003), in this century zoos have three main challenges: (i) reduce threats to species due to the reduction of their habitats, (ii) take into account ethical aspects, with regard to animal welfare and rights, and (iii) contribute to the knowledge of people immersed in an urbanized environment in relation to nature.

The increased interest of the public reaching 700 million visitors annually on wildlife conservation has resulted in a greater need for information and therefore has generated financial support for scientific research in this area. According to Conway (2001), a study commissioned by the Cleveland Zoological Society showed that new funds and donations to zoos have emerged from activities with education and scientific programs. More and more, conservation biologists recognize the important connections between in situ and ex situ studies for in situ conservation efforts, turning these entities into unique resources transforming these entities into unique resources (Conway 1969; Hutchins 1988; Olney et al. 1994; Rabb and Saunders 2005; Wildt 2000; Feistner 1992; Wiese and Hutchins 1993). Some studies that require sample collection, such as physiological and endocrine examinations, for example, were only possible in captive animals (Rabb and Saunders 2005). Thus, the combination of in situ and ex situ studies culminated in the transformation of some zoos and aquariums in conservation centers (IUDZG/CBSG 1993; Rabb 1994; Rabb and Saunders 2005).

According to Miller et al. (2004), for zoos to act effectively as wildlife conservation centers, it is necessary for such a policy to be defined with clear goals and objectives, maintaining a specific department to manage programs and fundings. Thus, zoos should contribute effectively to the protection of natural habitats, for example by participating in programs for the reintroduction of species and exposing their animals to naturalistic sites, so as to encourage their visitors to engage in nature conservation activities. It is also necessary to reevaluate the performance of their practices, monitoring, through scientific studies, all the mentioned aspects (Wagner et al., 2009). Some examples of guidelines and successful 
conservation programs can be seen in Kleiman et al. (1986), IUDZG/CBSG (1993), Odum and Reinert (2015), and World Association of Zoos and Aquariums (2016).

The Convention on Biological Diversity [in 1992] recognized the importance of participatory management with the efforts of managers, the scientific community, zoos and society as a whole. It looks like zoos may be the link between society and conservation programs.

\section{CAN VISITORS' PERCEPTION BE A QUALITY INDICATOR OF A ZOO?}

Visitors go to zoos to enjoy the outdoors, have a moment with their family, socialize, relax, come into contact with animals, take pictures of them, learn about them, entertain themselves and educate their children (lannacone and Alvariño 2011). However, the main reason for visiting zoos is still the one of the beginning of animal collection history: leisure (Ahmad et al. 2015; Fraser and Sickler 2009; Karanikola et al. 2014; Weiler et al. 2016). In addition to leisure, zoos can also be an important place to teach your children about animals (Alarape et al. 2015; lannacone and Alvariño 2011; Lee 2015; Morgan and Hodgkinson 1999; Packer and Ballantyne 2002). Although the main reason for visiting zoos is leisure, this does not belittle the main role that these institutions play, which is to make people think about life forms in nature (Garrett 2014; Lee 2015).

Zoos can have a major impact on visitors' perceptions of wildlife since these places allow contact with the animals and the construction of this perception (lannacone and Alvariño 2011; Weiler et al. 2016). Studies show that the main factors affecting this perception are the services provided in these institutions, such as whether it is a safe environment for a family walk, the question of animal isolation, and demonstrations with animals (Anderson et al. 2003; Gaengler and Clum 2015; Lee 2015; Ross et al. 2012), the diversity of species found (Carr 2016a, b; Ross and Gillespie 2009) and the design of the enclosures (Andersen 2003; Coe 1986; Davey 2006; Ross et al. 2012; Webber 2015). According to Birenboim et al. (2015), the quality of the experience, including the interactions with the animals, is another factor that affects visitors' perception.

When asked about the main objectives of zoos, visitors usually mentions aspects that include the four principles (conservation, research, education and leisure) (Ahmad et al. 2015; Puan and Zakaria 2007; Yilmaz et al. 2010). In this sense, although Fernandez et al. (2009) stated that animal welfare would be a fifth principle, Lee (2015) noted that attributes related to animal welfare were of little importance to visitors. This may indicate that, despite efforts to improve animal welfare, visitors do not recognize such efforts as one of the objectives of zoos (Aragão and Kazama 2014). In spite of this, we know that if the design of the enclosure is more similar to the natural environment it can positively influence the visitor's experience, as proven by Davey (2006), Powell and Bullock (2014) and Lee (2015). It is questioned whether it would be important to establish welfare as one of the principles, according to Fernandez et al. (2009).

Little has been studied on the attitudes and the behavior of visitors to the zoos (Hacker 2016; Ogden and Heimlich 2009). According to Ajzen (1991), visitors' behavior depends on their perceptions, beliefs and attitudes. Similarly, Joseph (2008) has shown that the motivation of the visit, past experiences, selfinterest, and knowledge are of the essence for environmentally 
responsible behavior. For this reason being aware of the importance of conservation is not always reflected in significant changes of behavior (Hacker 2016). The complex nature of conservationrelated behaviors makes them difficult to change. According to Webb and Sheeran (2006), intentions in favor of conservation shown by the visitors during their visit end up producing only small or medium behavioral changes. In this sense, the effectiveness of the educational role of zoos in changing behavior should be studied more indepth.

On the contrary, several studies from the late 1960s on show that visitors may interfere both with animal behavior and physiology (Fernandez et al. 2009; Hediger 1969; Hosey 2000; Hosey 2017; Hosey et al. 2016; Kelly et al. 2015; Scott et al. 2017; Sherwen et al. 2015; Sneddon et al. 2016; Thompson 1993; Webster et al. 2017; Wells et al. 2005). Studies that evaluated the simple presence, interaction, position of the visitor, besides the greater or lesser agglomeration of these, showed divergent results. In some of them, the results showed negative effects on animal behavior (Mallapur et al. 2005; Sellinger and $\mathrm{Ha} \mathrm{2005;}$ Wells et al. 2005) in other positive effects (Condon and Wehnelt 2003; Hosey and Druck 1987; Thompson 1993); other showed no effect (Fa 1989; Nimon and Dalziel 1992; O'Donovan et al. 1993). According to Davey (2007), the visitors' behaviors are unpredictable and difficult to control. Such behaviors range from inadequate food supply until screams, provocations and even throwing stones to draw the animal's attention. Behaviors such as these are certainly harmful to animal health and welfare and should be minimized through zoo educational programs (Davey 2007).

It seems that visitors' perceptions of the consequences of their own behavior, as well as their responsibility for biodiversity conservation, are limited in both thirdworld and economicallydeveloped countries. In 2011, lannacone and Alvariño conducted a study on visitors' perception at the Lima Zoo in Peru, where only $20 \%$ of them believed that environmental degradation and contamination was a problem to be faced by humanity. More recently, Weiler et al. (2016) showed that Australian visitors of the Victoria Zoo complex believed in the importance of biodiversity conservation, but they did not think they were responsible for it, attributing this to governmental entities. These results may be a reflection of an inadequate or non existent communication between the entities dedicated to the conservation of biodiversity and society.

Despite the difficulties of testing whether zoos' educational work helps change behavior during and after the visit, some studies have indicated that this is possible. Kratochvil and Schwammer (1997) realized in the Tiergarten Schönbrunn Aquarium in Vienna that visitors tapped less on the glass to draw attention when they had available information on the problems of this behavior for animal welfare. In another example, Kemmerly and Macfarlane (2009) showed that four months after a visit to the Monterey Bay Aquarium in the United States, and after receiving a pocket guide on seafood, visitors reported they had changed some habits related to the purchase of these animals and began showing a greater concern with conservation, adopting a more sustainable attitude [more information about the educational material of the Monterey Bay Aquarium is available at: http://www.montereybayaquarium.org/ /m/pdf/education/curriculum/aquarium35 whatsonthemenu.pdf?la=en].

Education and conservation are interdependent bedrocks and should be 
allied to studies on visitors' perception so that the zoos can achieve their goals in wildlife welfare. In this way, the success of zoological education programs should be improved for what concerns understanding the importance attributed by visitors to conservation (Gurusamy et al. 2015; Luebke et al. 2016). Zoos can lead visitors to achieve an overall understanding of biodiversity, as well as increase their knowledge about the actions that should be taken to help protect nature (Moss et al. 2015). This may be the way for the zoo's role in biodiversity conservation to be fulfilled.

\section{FUTURE PROSPECTS}

Much has changed since the first relationships between humans and animals. From mere utilitarian objects, animals have turned into fundamental beings in the consolidation of a more affective and caring relationship between humans and nature (Hancocks 2001). This relationship has been substantially shaped by zoos, which throughout history have changed the way we perceive animals. To this end, the best zoos have evolved, attaining today the status of research and animal conservation centers, with educational programs for their visitors.

Given that nowadays zoo activities are based on the idea that they can contribute to nature conservation, the question arises whether all existing zoos can attend to this purpose. Unfortunately, the answer to this question is no. According to Conway (1986), the spaces where animals are kept are still very small, with all the zoos enclosures in the world fitting in New York Brooklyn neighborhood. More recently, Lee (2015) warns that many zoos still maintain the old menageries structure, that is, they have concrete enclosures surrounded by iron bars, with little or no vegetation. The main justifications for these shortcomings are the insufficient investments in zoos structures, as well as problems in the management and even influence of the outdated but still present conception of the rulers and of society itself (Coe 2012; Conway 1986; Lee 2015; McNeely 1995). Therefore, the main challenge of zoos is overcoming these adversities to improve their structures and meet the four principles.

In order to become the conservation centers we need, zoos still have a number of obstacles to overcome. In this sense, social, political and economic obstacles throughout history cannot be disregarded, since as Conway (1986) and Coe (2012) say, these topics are directly related to zoos management. Changes in the way economic development is perceived, for example, by reducing consumerism and by creating alternatives for sustainable economic development, can have a positive impact on the perception of animal value (Berndes et al. 2003; Lorek and Spangenberg 2014; Mont, Neuvonen and Lähteenoja 2014). Moreover, the need of mankind to deal with the use of spaces for agricultural purposes in a more effective way, reducing waste and valuing agroecological crops (Schmitz et al. 2014) and the quality of life in large urban centers, shows significant social changes (Knox et al. 2014). People have begun to seek a reconnection with nature to improve their quality of life. In this sense, it is expected that these changes will enhance the valorization of bioparks, sanctuaries, safaris and immersion zoos near urban centers, as alternative sources for contact with nature (Coe 2012; McNeely 1995).

Even if these perspectives of zoological changes are real, these changes should occur faster than they actually do (Weiler et al. 2016). An alternative to speeding up this 
process is to make the visitor more critical of the structural features of zoos so that society as a whole, not just a small portion, requires more government investment in this area. Educational activities are therefore crucial for the population to acquire a more critical view of zoos with bad and/or outdated structures, and to generate feelings that are more affective towards nature and from which they can have more sustainable attitudes and behaviors (Hand et al. 2017; Ross et al. 2012; Wijeratne et al. 2014).

That said, we believe that the next step is to turn our attention to the visitors, not only to meet their leisure expectations, but for them to become allies in the fight for biodiversity conservation. The expansion of educational programs that are beyond the informational boards which are not restricted to school groups is of the utmost importance. Technology, such as a realtime interactive guide providing information on the animals during and after the visit, can be a tool to help the visitors' immersion into nature (Webber et al. 2017).

The consolidation of zoological organizations with the cooperation of a larger number of zoos and covering different regions of the world is also vital in order to expand studies on all bedrocks. The greater number of zoos involved, each with its peculiarities, could generate more comprehensive results, that is, results that could be used as parameters by other zoos worldwide. In addition, we would like to compare the methods used for the care of the same species in different zoos and thereby propose a minimum structural pattern to provide a greater wellbeing to the animals and a significant experience to visitors (Hancocks 2001).

From the above, we can see that there is still a lot to do in these institutions and, possibly, it will take more than 50 years to improve a good number of them. Accelerating this process would depend on a greater coordination of programs within and outside the target institutions. Thus, the search for efficiency of its bedrocks must be constant. Of course, leisure will remain the main attraction for visitors to a zoo, but any institution should also be able to ensure its existence through animal welfare and serious research, including conservation research. Finally, more effort is needed so that zoos can better contribute to visitors' environmental education. This is actually one of the most important goals of a zoo.

\section{CONCLUSIONS}

The main challenge of most zoos is overcoming insufficient investments, as well as problems in the management and influence of the outdated conception of the rulers and of society itself to improve their structures and meet the four principles. As zoos have had to overcome social, political, and economic difficulties throughout history, these obstacles must also be overcome for zoos to become excellences in conservation centers.

The loss of biodiversity demands a more rapid change in people's attitudes and behavior. For this, zoos need to intensify the engagement of visitors for conservation throughout educational activities that are crucial for the population to acquire a more critical view of zoos with bad and/or outdated structures. The consolidation of zoological organizations with the cooperation of a larger number of zoos by covering different regions of the world is vital in order to expand scientific studies all areas of actuation of zoo. Entertainment always will remain the main attraction for visitors to a zoo, but any institution should also be able to ensure its existence through animal 
welfare, research, conservation and education.

\section{ACKNOWLEDGEMENTS}

We thank the Tiergarden Schönbrunn for granting use of Figure 5 and also the Berlin Zoo for the information provided on Figure 6. This study was funded by a PhD grant (IBPG 15457.06/14) from Fundação do Amparo à Ciência e Tecnologia (FACEPE) awarded to Marilian Boachá Sampaio.

\section{REFERENCES}

Acampora RR (1998) Extinction by exhibition: Looking at and in the zoo. Human Ecology Review 5:14.

Ahmad S, Ali Z, Nemat A, Sikander SK, Hussain Z, Saleem K. (2015) The study of public perception for captive animals at Lahore zoo, Pakistan. The Journal of Animal and Plant Sciences 25:509513.

Ajzen I (1991) The theory of planned behavior. Organizational Behavior and Human Decision Processes 50:179211.

Alarape AA, Yager GO, Salman KK (2015) Assessment of tourists satisfaction and perception in Makurdi Zoological Garden, Benue State, Nigeria. Journal of Research in Forestry, Wildlife and Environment 7:112.

Almeida AV, Oliveira MAB, Meunier IMJM (2011) Animais e plantas do horto zoobotânico do palácio de Friburgo (16391645) construído por Maurício de Nassau no Recife. Filosofia e História da Biologia 6:1935.

Alves RRN, Lechner W (2018) Wildlife Attractions: Zoos and Aquariums in: Alves, R.R.N., Albuquerque, U.P. (Eds.), Ethnozoology: Animals in our lives. Academic Press, Elsevier, pp. 351361.

Alves RRN, Souto WMS (2015) Ethnozoology: A Brief Introduction. Ethnobiology and Conservation 4, 1-13.

Andersen LL (2003) Zoo education: from formal school programmes to exhibit design and interpretation. International Zoo Yearbook 38:7581.
Anderson US, Kelling AS, PressleyKeough R, Bloomsmith MA (2003) Enhancing the zoo visitor's experience by public animal training and oral interpretation at an otter exhibit. Environment and Behavior 35:826841.

Aragão GMO, Kazama R (2014) Percepção sobre o bemestar de animais silvestres no Zoológico de Brasília como ferramenta para educação ambiental. Ambiente and Educação 19:3350.

Artursson M, Earle T, Brown J (2016) The construction of monumental landscapes in lowdensity societies: New evidence from the Early Neolithic of Southern Scandinavia (4000 - $3300 \mathrm{BC}$ ) in comparative perspective. Journal of Anthropological Archaeology 41:118.

Bagarinao T (1998) Nature parks, museums, gardens, and zoos for biodiversity conservation and environment education: The Philippines. Ambio 27:230237.

Ballantyne R, Packer J (2016) Visitors' perceptions of the conservation education role of zoos and aquariums: Implications for the provision of learning experiences. Visitor Studies 19:193210.

Bauer BS (2004) Ancient Cuzco: heartland of the Inca. University of Texas Press, Austin.

Beardsworth A, Bryman A (2001) The wild animal in late modernity: The case of the Disneyization of zoos. Tourist Studies 1:83104.

Bennett ET (1829) The Tower Menagerie. R. Jennings, London.

Berlin B (1973) Folk systematics in relation to biological classification and nomenclature. Annual review of ecology and systematics 4:259 271.

Berndes G, Hoogwijk M, Van Den Broek R (2003) The contribution of biomass in the future global energy supply: A review of 17 studies. Biomass and Bioenergy 25:128.

Bertram B (2004) Misconceptions about zoos. Biologist 51:199206.

Birenboim A, Reinau KH, Shoval N, Harder H (2015) Highresolution measurement and analysis of visitor experiences in time and space: The case of Aalborg zoo in Denmark. Professional Geographer 67:620629.

Birney BA (1997) Conserving within cultural contexts. Zoo Biology 16:8991. 
Bostock SSC (1993) Zoos and animal rights: The ethics of keeping animals. Routledge, New York.

Brading DA (1986) The Incas and the Renaissance: the royal commentaries of Inca Garcilaso De la Veja. Journal of Latin American Studies 18:123.

Breasted JH (1906) Ancient Records of Egypt. University of Chicago Press, Chicago.

Brown T (2014) "Zoo proliferation" The first British Zoos from 18311840 Entwicklungsjahre und Blütezeit Die ersten britischen Zoos von 18311840. Der Zoologische Garten 83:1727.

Burckhardt J (1878) The civilisation of the Renaissance in Italy. Macmillan, New York, pp. 294295.

Buren EDV (1939) The fauna of ancient mesopotamia as represented in art. In: Analecta Orientalia 18. Pontificum institutum biblicum, Rome, pp 113.

Carr N (2016a) Star attractions and damp squibs at the zoo: a study of visitor attention and animal attractiveness. Tourism Recreation Research 41:326338.

Carr N (2016b) Ideal animals and animal traits for zoos: General public perspectives. Tourism Management 57:3744.

Carr N. and Cohen, S. (2011) The public face of zoos: Images of entertainment, education, and conservation. Anthrozoos 24:175189.

Chávez KLM (1980) The archaeology of Marcavalle, in early horizon site in the Valley of Cuzco, Peru. D. Reimer, pp. 107205.

Clark G, Piggott S (1965) Prehistoric societies. Hutchinson, New York.

CluttonBrock J (1981) Domesticated animals from early times. University Texas Press, Austin.

Coe J (2012) Design and architecture: third generation conservation, post immersion and beyond. Future of Zoos Symposium, 1011.

Coe JC (1986) Towards a coevolution of zoos, aquariums and natural history museums. Annual Conference Proceedings, American Association of Zoological Parks and Aquariums, 366376.

Coleman W (1964) George Cuvier, Zoologist: A study in the history of evolution theory. Harvard University Press, Cambridge.
Collins BJ (1989) The representation of wild animals in Hittite texts. Ph.D. Dissertation, Yale University, New Haven, CT.

Condon E, Wehnelt S (2003) The effect of visitors on the behaviour of Humboldt's penguins at Chester Zoo. Federation Research Newsletter 4:3.

Conway WG (1986) The practical difficulties and financial implications of endangered species breeding programmes. International Zoo Yearbook 24:210219.

Conway W (1969) Zoos: Their changing roles.

Science 163:4852.

Conway W (1995) Wild and zoo animal interactive management and habitat conservation. Review of Industrial Organization 4:573594.

Conway W (2001) AZA field conservation resource guide. pp. 17.

Cooper JE (1981) Bacteria. In: Cooper JE, Jackson OF (eds.) Diseases of the Reptilia. Academic Press, London, England, pp. 165191.

Cooper M (2003) Zoo legislation. International Zoo Yearbook 38:8193.

Cornell T (2012) The beginnings of Rome: Italy and Rome from the Bronze Age to the Punic Wars (c. 1000-264 BC). Routledge.

Coues $E(1876)$ The destruction of birds by telegraph wire. The American Naturalistic 10:734736.

Crosby AW (1986) Ecological Imperialism: The biological expansion of Europe, 900-1900. Cambridge University Press, New York.

Dale RHI (2010) Birth statistics for African (Loxodonta africana) and Asian (Elephas maximus) elephants in human care: History and implications for elephant welfare. Zoo Biology 29:87103.

Dalley S (1993) Ancient Mesopotamian gardens and the identification of the hanging gardens of Babylon resolved. Garden History 21:113.

Darwin C (1859) On the origin of the species by natural selection. D Appleton and Company, New York.

Darwin C (1868) The variation of animals and plants under domestication. Orange Judd and Co., New York.

Davey G (2006) Visitor behavior in zoos: A review. Anthrozoos 19:143157. 
Davey G (2007) Visitors' effects on the welfare of animals in the zoo: a review. Journal of Applied Animal Welfare Science 10:169183.

D'Elia J (2010) Evolution of avian conservation breeding with insights for addressing the current extinction crisis. Journal of Fish and Wildlife Management 1:189 210.

De La Fuente MFC, Souto A, Caselli CB, Schiel $\mathrm{N}(2017) \quad$ People's perception on animal welfare: why does in matter? Ethnobiology and Conservation 6:17.

De La Vega G, Livermore HV (1964) Royal commentaries of the Incas. Franklin.

Dodson J, Dong G (2016) What do we know about domestication in eastern Asia? Quaternary International 426:29.

Eaton RL (1981) An Overview of Zoo Goals and Exhibition Principles. International Journal for the Study of Animal Problems 2:295299.

Erman A (1984) Life in Ancient Egypt. Dover Publications, New York.

ErpHoutepen AV (1986) The etymological origin of the Garden. The Journal of Garden History 6:227231.

Fa JE (1989) Influence of people on the behavior of display primates. In: Segal EF (ed) Housing, Care and Psychological Wellbeing of Captive and Laboratory Primates. Noyes Publications: Park Ridge, 270290.

Famula TR (2014) Domestication of animals. In: Encyclopedia of Agriculture and Food Systems 2:462473.

Feistner ATC (1992) Research at the Jersey Wildlife Preservation Trust. The Dodo: journal of the Jersey Wildlife Preservation Trust 28:153 65.

Feistner ATC, Sterling ES (Eds) (1994) The aye aye: Madagascar's most puzzling primate. Folia Primatology 62:13.

Fernandez EJ, Tamborski MA, Pickens SR, Timberlake W (2009) Animalvisitor interactions in the modern zoo: Conflicts and interventions. Applied Animal Behaviour Science 120:18.

Finkel IL (1988) The hanging gardens of Babylon. In: Clayton PA, Price MJ (eds) The Seven Wonders of the Ancient World. Routledge, London.
Fisher J (1967) Zoos of the world: the story of animals in captivity. American Museum of Natural History, New York.

Frankham R, Briscoe DA, Ballou JD (2002) Introduction to conservation genetics. Cambridge University Press, Cambridge.

Fraser J, Sickler J (2009) Measuring the cultural impact of zoos and aquariums. International Zoo Yearbook 43:103112.

Fuller E (1987) Extinct birds. Viking/Rainbird, London.

Gaengler H, Clum N (2015) Investigating the impact of large carcass feeding on the behavior of captive Andean condors (Vultur gryphus) and its perception by Zoo Visitors.

Zoo Biology 34:118129.

Garrett EA (2014) Why do we go to the zoo: communication, animals, and the cultural historical experience of zoos. The Fairleigh Dickinson University Press, New Jersey.

Gaskell J (2000) Who killed the Great Auk? Oxford University Press, Oxford.

George M, Chemnick LG, Cisova D, Gabrisova E, Stratil A, Ryder OA (1993) Genetic differentiation of white rhinoceros subspecies: diagnostic differences in mitochondrial DNA and serum proteins. In: Ryder OA (ed.) Proceedings International conference on rhinoceros conservation and biology. Zoological Society of San Diego, pp. 105113.

George W (1969) Animals and maps. University of California Press, Berkeley.

George W (1980) Sources and background to discoveries of new animals in the sixteenth and seventeenth centuries. History of science 18:79104.

George W (1985) Alive or dead: zoological collections in the seventeenth century. In: Impey $\mathrm{O}$, Macgregor $\mathrm{A}$ (Eds) The Origins of Museums: the Cabinet of Curiosities in Sixteenth and SeventeenthCentury Europe. Oxford University Press, Oxford.

Gippoliti S (2005) Historical museology meets tropical biodiversity conservation. Biodiversity and Conservation 14:31273134.

Goudie AS (2013) The human impact on the natural environment: past, present, and future. WileyBlackwell, New Jersey. 
Green RE, Cornell SJ, Scharlemann JPW, Balmford A (2005) Farming and the fate of wild nature. Science 307:550555.

Grigson C (2016) Menagerie: The history of exotic animals in England. Oxford University Press, Oxford.

Grove RH (1995) Green Imperialism: Colonial Expandion, tropical island Edens and the origins of environmentalism. Cambridge University Press, Cambridge.

Gurusamy V, Tribe A, Toukhsati S, Phillips CJ (2015) Public attitudes in India and Australia toward elephants in zoos. Anthrozoös 28:87 100.

Gusset M, Dick G (2011) The global reach of zoos and aquariums in visitor numbers and conservation expenditures. Zoo Biology 30:566569.

Gutiérrez-Santillán TV, Albuquerque UP, ValenzuelaGalván D, Reyes-Zepeda F, Vázquez LB, Mora-Olivo A, Arellano-Méndez LU (2018) Trends on mexican ethnozoological research, vertebrates case: a systematic review. Ethnobiology and Conservation 9:1-39.

Hacker CE, Miller LJ (2016) Zoo visitor perceptions, attitudes, and conservation intent after viewing African elephants at the San Diego Zoo Safari Park. Zoo Biology 35:355361.

Hagenbeck C (1909) Beasts and men. Longmans, Green and Co., London.

Hancocks D (1980) Naturalistic solutions to zoo design problems. In: Stevens $P(E d)$ Third international symposium on zoo design and construction. Paignton, U.K.: Whitley Wildlife Trust, pp. 16673.

Hancocks $D(2001)$ Is there a place in the world for zoos? In: Salem DJ, Rowan AN (Eds) The state of the animals. Humane Society Press, Washington, DC, 137-147.

Hand KL, Freeman C, Seddon PJ, Recio MR, Stein A, Heezik YV (2017) The importance of urban gardens in supporting children's biophilia. Proceedings of the National Academy of Sciences of the United States of America 114:274279.

Harley EH, O'ryan C (1993) Molecular genetic studies of southern African rhinoceros. In: Ryder OA (Ed) Proceedings, International conference on rhinoceros conservation and biology. Zoological Society of San Diego, San Diego, pp. 101104.
Hediger H (1969) Man and animal in the zoo. Routledge and Kegan Paul, London, p. 303.

Heindl G (2015) Schoenbrunn Zoo in world war I. Der Zoologische Garten 85:1334.

Heneson N (1981) Getting educated at the zoo. Animal Studies Repository 2:282283.

Hoage RJ, Deiss WA (Eds.) (1996) New Worlds, new animals: from menagerie to zoological park in the nineteenth century. Johns Hopkins University Press, Baltimore.

Hochadel O (2005) Science in the 19thcentury zoo. Endeavour 29:3842.

Hosey GR, Druck PL (1987) The influence of zoo visitors on the behaviour of captive primates. Applied Animal Behaviour Science 18:1929.

Hosey GR (2000) Zoo animals and their human audiences: what is the visitor effect? Animal Welfare 9:343357.

Hosey G (2017) Visitor effects. The International Encyclopedia of Primatology, pp.1 5.

Hosey G, Melfi V, Formella I, Ward SJ, Tokarski M, Brunger D, Hill SP (2016) Is wounding aggression in zoohoused chimpanzees and ringtailed lemurs related to zoo visitor numbers? Zoo Biology 35:205209.

Howell A, Neal AW (2012) Human interest and humane governance in iraq: humanitarian war and the Baghdad zoo. Journal of Intervention and Statebuilding 6:213232.

Hutchins $M(1988)$ On the design of zoo research programmes. International Zoo Yearbook 27:919.

Hutchins M (2003) Zoo and aquarium animal management and conservation: current trends and future challenges. International Zoo Yearbook 3:81.

lannacone J, Alvariño L (2011) Percepción ambiental de los visitantes a un zoológico de Lima, Perú. Biotempo 11:3642.

Ingold T (1994) Grom trust to domination: an alternative history of humananimal relations. In: Manning A, Serpell J (eds.) Animals and Human Society: Changing perspectives. Routledge, London, pp. 122.

ludzg/Cbsg (IUCN/SSC) (1993) The world zoo conservation strategy: the role of the zoos and aquaria of the world in global conservation. Chicago Zoological Society, Brookfield. 
Ize (2016) International Zoo Educators Associacion Journal 52:68.

Jamieson D (1985) Against zoos. Environmental Ethics: Readings in Theory and Application 5:97 103.

Jennison G(1937) Animals for show and pleasure in ancient rome. Manchester University Press, Manchester.

Jordan B, Ormrod S (1978) Last great wild beast show. Constable and Co., Edinburgh.

Joseph S (2008) From visit to action: how zoo visitor characteristics influence environmentally responsible behavior. All Theses, 84.

Kalof $L$ (2007) Looking at animals in human history. Reaktions Book, London.

Karanikola P, Tampakis S, Tsantopoulos G, Digbasani C (2014) The public zoo as recreation and environmental education area: visitor's perceptions and management implications. WSEAS Transactions on Environment and Development 10:8191.

Kellert SR (1993) Attitudes, knowledge, and behavior toward wildlife among the industrial superpowers: United States, Japan, and Germany. Journal of Social Issues 49:5369.

Kelly JD (1997) Effective conservation in the twentyfirst century: the need to be more than a zoo. One organization's approach. International Zoo Yearbook 35:114.

Kelly KR, Harrison ML, Size DD, Macdonald SE (2015) Individual effects of seasonal changes, visitor density, and concurrent bear behavior on stereotypical behaviors in captive polar bears (Ursus maritimus). Journal of Applied Animal Welfare Science 18:1731.

Kemmerly JD, Macfarlane V (2009) The elements of a consumerbased initiative in contributing to positive environmental change: Monterey bay Aquarium's seafood watch program. Zoo Biology 28:398411.

Kisling VNJ (1998) Colonial menageries and the exchange of exotic faunas. Archives of Natural History 25:303320.

Kisling VNJ (2001) Zoo and aquarium history: ancient animal collections to zoological gardens. CRC Press, New York, 415.
Kleiman DG, Beck BB, Dietz JM, Dietz LA, Ballou JD, CoimbraFilho AF (1986) Conservation program for the golden lion tamarin: captive research and management, ecological studies, educational strategies, and reintroduction. In: BENIRSCHKE $\mathrm{K}$ (ed) Primates the road to selfsustaining populations. SpringerVerlag, New York, pp. 959 979.

Kleiman DG (1983) Ethology and reproduction of captive giant pandas (Ailuropoda melanoleuca). Ethology 62:146.

Kleiman DG (1992) Behavior research in zoos: Past, present, and future. Zoo Biology 11:301 312.

Klimczak N (2016) Montezuma Zoo: A Legendary Treasure of the Aztec Empire. http://www.ancientorigins.net/ancientplaces americas/montezumazoolegendarytreasure aztecempire005090. Acessed 09 august 2017.

Knox P, Agnew JA, Mccarthy L (2014) The geography of the world economy. Routledge, London.

Knowles JM (2003) Zoos and a century of change. International Zoo Yearbook 38:2834.

Kratochvil H, Schwammer H (1997) Reducing acoustic disturbances by aquarium visitors. Zoo Biology 16:349353.

Lawrence N (2012) The prime minister and the platypus: A paradox goes to war. Studies in History and Philosophy of Biological and Biomedical Sciences 43:290297.

Lee HS (2015) Measurement of visitors' satisfaction with public zoos in Korea using importanceperformance analysis. Tourism Management 47:251260.

Loisel G (1912) Histoire des ménageries de l'antiquité a nos jours. H. Laiirens and O. Doin, Paris.

Lonsdale SH (1979) Attitudes toward animals in ancient Greece. Greece and Rome 26:146 159.

Lorek S, Spangenberg JH (2014) Sustainable consumption within a sustainable economy-beyond green growth and green economies. Journal of cleaner production 63:33 44. 
Luebke JF, Watters JV, Packer J, Miller LJ, Powell DM (2016) Zoo visitors' affective responses to observing animal behaviors. Visitor Studies 19:6076.

Maehle AH (1994) Cruelty and kindness to the" brute creation:" Stability and change in the ethics of the mananimal relationship, 1600-1850. In: Manning A, Serpell J (eds) Animals and human society: Changing perspectives. Routledge and Taylor and Francis Group, London and New York.

Mallapur A, Waran N, Sinha A (2005) Factors influencing the behaviour and welfare of captive liontailed macaques in Indian zoos. Applied Animal Behaviour Science 91:337353.

Mayr E (1942) Systematics and the origin of species, from the viewpoint of a zoologist. Harvard University Press, Cambridge.

Mcneely JA (1995) Expanding partnerships in conservation. Island Press, Washington, DC.

Meffe GK, Carroll CR (1997) Principles of conservation biology. 2nd Edition. Sinauer Associates, Sunderland, MA.

Menzies NK (1994) Forest and land management in Imperial China. St. Martin's Press, New York.

Meyer $\mathrm{T}$ (1889) Extinction of our birds. Ornithologists' and Oologists' SemiAnnual 1:28 29

Miller B, Conway W, Reading RP, Wemmer C, Wildt D, Kleiman D, Hutchins M (2004) Evaluating the conservation mission of zoos, aquariums, botanical gardens, and natural history museums. Conservation Biology 18:18.

Mohnhaupt $J(2016)$ The zoo of the others: Relationship and competition between the two Berlin Zoos during the Cold War. Mammalian Biology 81:14.

Mont O, Neuvonen A, Lähteenoja S (2014) Sustainable lifestyles 2050: Stakeholder visions, emerging practices and future research. Journal of Cleaner Production 63:24 32.

Morgan JM, Hodgkinson M (1999) The motivation and social orientation of visitors attending a contemporary zoological park. Environment and Behavior 31:227239.

Moss A, Esson M (2013) The educational claims of zoos: where do we go from here? Zoo Biology 32:1318.
Moss A, Jensen E, Gusset M (2015) Evaluating the contribution of zoos and aquariums to Aichi Biodiversity Target 1. Conservation Biology 29:537544.

Needham J (1954) Science and civilisation in China. Cambridge University Press, London.

Nimon AJ, Dalziel FR(1992) Crossspecies interaction and communication: a study method applied to captive siamang (Hylobates syndactylus) and longbilled corella (Cacatua tenuirostris) contacts with humans. Applied Animal Behaviour Science 33:261272.

O'donovan D, Hindle JE, Mckeown S, O'donovan $S$ (1993) Effect of visitors on the behaviour of female cheetahs Acinonyx jubatus. International Zoo Yearbook 32:238244.

Odum RA, Reinert HK (2015) The Aruba island rattlesnake crotalus unicolor species survival plan: A case history in ex situ and in situ conservation. International Zoo Yearbook 49:104112.

Ogden J, Heimlich JE (2009) Why focus on zoo and aquarium education? Zoo Biology 28:357 360.

Olney PJS, Mace GM, Feistner ATC (1994) Creative conservation, interactive management of wild and captive animals. Chapman and Hall, London.

Osborne MA (1994) Nature, the exotic, and the ccience of French Colonialism. Indiana University Press, Bloomington.

Osborne M (2000) Acclimatizing the world: a history of the paradigmatic colonial science. Osiris 15:135151.

Packer J, Ballantyne R (2002) Motivational factors and the visitor experience: a comparison of three sites. Curator 45:183198.

Patrick BPG, Matthews CE, Ayers DF, Tunnicliffe SD (2007) Conservation and education: prominent themes in zoo mission statements. The Journal of Environmental Education 38:53 60.

Powell DM, Bullock EVW (2014) Evaluation of factors affecting emotional responses in zoo visitors and the impact of emotion on conservation mindedness. Anthrozoos 27:389 405. 
Primack RB (2002) Essentials of conservation biology. Sinauer Associates, Sunderland, Massachusetts.

Puan CL, Zakaria M(2007) Perception of visitors towards the role of zoos: A Malaysian perspective. International Zoo Yearbook 41:226 232.

Rabb GB, Saunders CD (2005) Guest essay. Environmental Protection 39:126.

Rabb GB (1994) The changing roles of zoological parks in conserving biological diversity. Integrative and Comparative Biology 34:159164.

Rees PA (2011) An introduction to zoo biology and management. John Wiley and Sons, pp. 117119.

Robeyns G (2012) Special wishes for the members of Antwerp zoo: 65 years of history in pictures (18501914). Der Zoologische Garten 81:1479.

Robinson MH (1987) Beyond the zoo: the biopark. Defenders 62:10.

Robinson MH (1992) Global change, the future of biodiversity and the future of zoos. Biotropica 24(2b):345352.

Ross SR, Gillespie KL (2009) Influences on visitor behavior at a modern immersive Zoo exhibit. Zoo Biology 28:462472.

Ross SR, Melber LM, Gillespie KL, Lukas KE (2012) The impact of a modern, naturalistic exhibit design on visitor behavior: $A$ cross facility comparison. Visitor Studies 15:315.

Rothfels N (2002) Savages and beasts: The birth of the modern zoo. John Hopkins University Press, Baltimore.

Rupke N (1994) Richard Owen: Victorian naturalist. Yale University Press, New Haven.

Ryder OA, Chemnick LG (1993) Chromosomal and mitochondrial variation in orangutans. Journal of Heredity 84:405409.

Ryder OA, Feistner ATC (1995) Research in zoos: A growth area in conservation. Biodiversity and Conservation 4:671677.

Sahlins P (2012) The royal menageries of Louis XIV and the civilizing process revisited. French Historical Studies 35:237267.

Sampaio MB, De La Fuente MF, Albuquerque UP, Da Silva Souto A, Schiel N (2018) Contact with urban forests greatly enhances children's knowledge of faunal diversity. Urban Forestry and Urban Greening 30:5661.
Schafer EH (1968) Hunting parks and animal. Journal of the Economic and Social History of the Orient 11:318343.

Schmitz C, Meijl HV, Kyle P, Nelson GC, Fujimori $S$, Gurgel A, Valin H (2014) Landuse change trajectories up to 2050: Insights from a global agroeconomic model comparison. Agricultural Economics (United Kingdom) 45:6984.

Schwabe CW (1994) Animals in the ancient world. In: Animals and human society: Changing perspectives (Eds. A. Manning and J. Serpell). Routledge, London, 36-58.

Scott K, Heistermann M, Cant MA, Vitikainen EIK (2017) Group size and visitor numbers predict faecal glucocorticoid concentrations in zoo meerkats. Royal Society Open Science 4:111.

Scullard HH (1974) The elephant in the Greek and Roman world. Thames and Hudson, London.

Segawa H (1993) Brazilian colonial gardens and the Rio de Janeiro passeio público. The Journal of Garden History 13:213223.

Seidensticker J, Doherty JG (1996) Integrating animal behavior and exhibit design. National Zoological Park, Washington, D.C.

Sellinger RL, Ha JC (2005) The effects of visitor density and intensity on the behavior of two captive jaguars (Panthera onca). Journal of Applied Animal Welfare Science 8:233 244.

Sherwen SL, Harvey TJ, Magrath MJL, Butler KL, Fanson KV, Hemsworth PH (2015) Effects of visual contact with zoo visitors on black capped capuchin welfare. Applied Animal Behaviour Science 167:6573.

Sneddon J, Lee J, Ballantyne R, Packer J (2016) Animal welfare values and tourist behaviour. Annals of Tourism Research 57:234236.

Soulé M, Noss R (1998) Rewilding and biodiversity: complementary goals for continental conservation. Wild Earth, pp. 18 28.

Stauffer RC (1975) Charles Darwin's natural selection: being the second part of his big species book written from 1856 to 1858. Cambridge University Press, London.

Stevens PMC, Mcalister E (2003) Ethics in zoos. International Zoo Yearbook, 38.

Strehlow H (2001) Zoologischer garten basel. Zoo Basel. 2 vol. Christoph Merian Verlag. Basel: pp 248. 
Szücs E, Geers R, Jezierski T, Sossidou EN, Broom DM (2012) Animal welfare in different human cultures, traditions and religious faiths. AsianAustralasian Journal of Animal Science 25:14991506.

The Zoological Society Of London (2016) Index to list of zoos and aquariums of the world. International Zoo Yearbook 50:392406.

Thompson SD (1993) Zoo research and conservation: Beyond sperm and eggs toward the science of animal management. Zoo Biology 12:155159.

Tomas S, Scott D, Crompton J (2002) An investigation of the relationships between quality of service performance, benefits sought, satisfaction and future intention to visit among visitors to a zoo. Managing Leisure 7:239250.

Vigne JD (2011) The origins of animal domestication and husbandry: A major change in the history of humanity and the biosphere. Comptes Rendus - Biologies 334:171181.

Wagner K, Chessler M, York P, Raynor J (2009) Development and implementation of an evaluation strategy for measuring conservation outcomes. Zoo Biology 28:473 487.

Webber S, Carter M, Smith W, Vetere F (2017) Interactive technology and human-animal encounters at the zoo. International Journal of Human Computer Studies 98:150168.

Webber S (2015) Design and evaluation of interactive technology for humananimal encounters at the zoo. Proceedings of the 12th International Conference on Advances in Computer Entertainment Technology, 1113.

Webb TL, Sheeran P (2006) Does changing behavioral intentions engender behavior change? A metaanalysis of the experimental evidence. Psychological bulletin 132:249268.

Webster K, Narayan E, Vos N (2017) Fecal glucocorticoid metabolite response of captive koalas (Phascolarctos cinereus) to visitor encounters. General and Comparative Endocrinology 244:157163.
Weiler B, Skibins J, Markwell K, Saunders R, Dunstan E (2016) Eliciting and modelling zoo visitors' values as predictors of receptiveness to interpretive messages, emotions and behavioural intentions. School of Business and Tourism 39:138.

Wells DL, Hepper PG, Coleman D, Challis MG (2005) A note on the effect of olfactory stimulation on the behaviour and welfare of zoohoused gorillas. Applied Animal Behaviour Science 106:155160.

Wiese R, Hutchins M (1993) The role of captive breeding and reintroduction in wildlife conservation. Proceedings, American Association of Zoological Parks and Aquariums Regional Conferences, Wheeling.

Wijeratne AJC, Dijk PAV, KirkBrown A, Frost L (2014) Rules of engagement: The role of emotional display rules in delivering conservation interpretation in a zoobased tourism context. Tourism Management 42:149 156.

Wildt DE (2000) Genome resource banking for wildlife research, management, and conservation. ILAR Journal/National Research Council, Institute of Laboratory Animal Resources 41:22834.

Wilkinson A (1994) Symbolism and design in ancient egyptian gardens. Garden History 22:1 17.

Wilson EO (1984) Biophilia. Harvard University Press, Cambridge.

Wirtz PH (1997) Zoo city: Bourgeois values and scientific culture in the industrial landscape. Journal of Urban Design 2:6182.

Wood CA, Fyfe FM (1943) The art of falconry by Frederick II of Hohenstaufen. Stanford University Press, Stanford.

Woodland Park Zoo (2015) Index to list of zoos and aquariums of the world. International Zoo Yearbook, 392406.

Woods B (2002) Good zoo/bad zoo: Visitor experiences in captive settings. Anthrozoös 15:343360.

Woollard SP (1998) The development of zoo education. International Zoo News 45:422426.

World Association of Zoos and Aquariums (2016)

Future of zoos and aquatiums design 17:48. 
Yilmaz S, Mumcu S, Özbilen A (2010) Effects of spatial differences on visitor perceptions at zoo exhibits. Scientific Research and Essays $5: 23272340$
Zeuner FE (1963) A history of domesticated animals. Hutchinson, London.
Received: 10 June 2019

Accepted: 22 December 2019

Published: 15 January 2020 